\section{orm}

OAK RIDGE

NATIONAL

LABORATORY

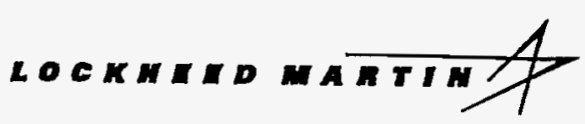

PECENS:

MAN 23 Mis

OSTI

\title{
Results of the Independent Radiological Verification Survey of the Remedial Action Performed at the Former Alba Craft Laboratory Site Oxford, Ohio (OXO001)
}

K. R. Kleinhans

M. E. Murray

R. F. Carrier

\section{DISCLAIMER}

MANAGED BY

LOCKHEED MARTIN ENERGY SYSTEMS, INC.

FOR THE UNITED STATES

DEPARTMENT OF ENERGY
This report was prepared as an account of work sponsored by an agency of the United States Government. Neither the United States Government nor any agency thereof, nor any of their employees, makes any warranty, express or implied, or assumes any legal liability or responsibility for the accuracy, completeness, or usefulness of any information, apparatus, product, or process disclosed, or represents that its use would not infringe privately owned rights. Reference herein to any specific commercial product, process, or service by trade name, trademark, manufacturer, or otherwise does not necessarily constitute or imply its endorsement, recommendation, or favoring by the United States Government or any agency thereof. The views and opinions of authors expressed herein do not necessarily state or reflect those of the United States Government or any agency thereof. 
This report has been reproduced directly from the best available copy.

Available to DOE and DOE contractors from the Office of Scientific and Technical Information, P.O. Box 62, Oak Ridge, TN 37831; prices available from (615) 576-8401, FTS 626-8401.

Available to the public from the National Technical Information Service, U.S. Department of Commerce, 5285 Port Royal Rd., Springfield, VA 22161.

This report was prepared as an account of work sponsored by an agency of the United States Government. Neither the United States Government nor any agency thereof, nor any of their employees, makes any warranty, express or implied, or assumes any legal liability or responsibility for the accuracy, completeness, or usefulness of any information, apparatus, product, or process disclosed, or represents that its use would not infringe privately owned rights. Reference herein to any specific commercial product, process, or service by trade name, trademark, manufacturer, or otherwise, does not necessarily consttute or imply its endorsement, recommendation, or favoring by the United States Government or any agency thereof. The views and opinions of authors expressed herein do not necessarily state or reflect those of the United States Government or any agency thereof. 


$$
\begin{array}{r}
\text { ORNL/TM-- } 12968 \\
\text { ORNL/TM-12968 }
\end{array}
$$

\title{
HEALTH SCIENCES RESEARCH DIVISION
}

Environmental Restoration and Waste Management Non-Defense Programs (Activity No. EX 2020 010)

\section{Results of the Independent Radiological Verification Survey of the Remedial Action Performed at the Former Alba Craft Laboratory Site, Oxford, Ohio (OXO001)}

\author{
K. R. Kleinhans, * M. E. Murray, and R. F. Carrier
}

Date of publication - April 1996

Investigation Team

R. D. Foley-Measurement Applications and Development Manager

M. E. Murray-Radiological Program Director

K. R. Kleinhans* - Survey Team Leader

Survey Team Members

\author{
J. F. Allred \\ A. C. Butler** \\ G. H. Cofer \\ M. E. Murray \\ R.L. Coleman \\ V.P. Patania \\ R. C. Gosslee \\ D. E. Rice \\ R. C. Gosslee \\ D. A. Rose \\ S. A. McKenzie \\ R. E. Rodriguez \\ D. D. Mckinney** \\ P.F. Tiner \\ J. Wade \\ W. A. Williams $†$ \\ W. Winton \\ *Former employee of Martin Marietta Energy Systems, Inc \\ **Midwest Technical, Inc. \\ †ेU.S. Department of Energy \\ Work performed by the \\ Measurement Applications and Development Group \\ Prepared by the \\ OAK RIDGE NATIONAL LABORATORY \\ Oak Ridge, Tennessee 37831-6285 \\ managed by \\ LOCKHEED MARTIN ENERGY RESEARCH CORP. \\ for the \\ U. S. DEPARTMENT OF ENERGY \\ under contract DE-AC05-960R22464
}





\section{CONTENTS}

LIST OF FIGURES $\ldots \ldots \ldots \ldots \ldots \ldots \ldots \ldots \ldots \ldots \ldots \ldots \ldots \ldots \ldots \ldots \ldots \ldots \ldots \ldots \ldots \ldots$ iii

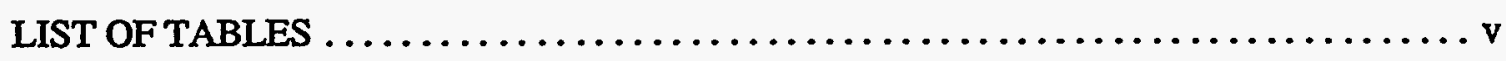

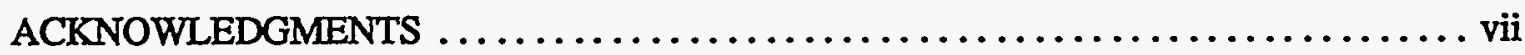

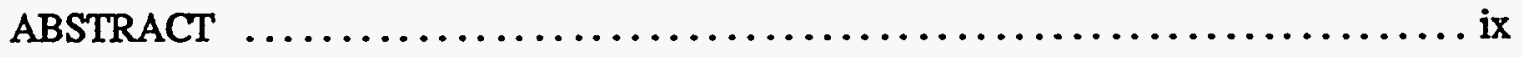

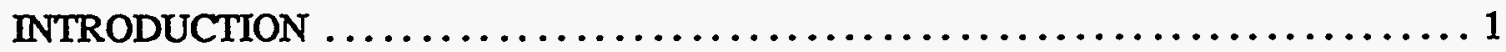

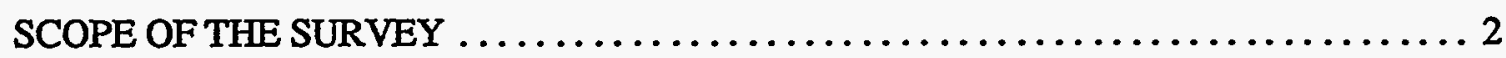

SURVEY METHODS $\ldots \ldots \ldots \ldots \ldots \ldots \ldots \ldots \ldots \ldots \ldots \ldots \ldots \ldots \ldots \ldots \ldots \ldots$

SURFACE RADIATION MEASUREMENTS $\ldots \ldots \ldots \ldots \ldots \ldots \ldots \ldots \ldots \ldots 2$

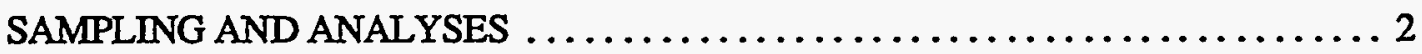

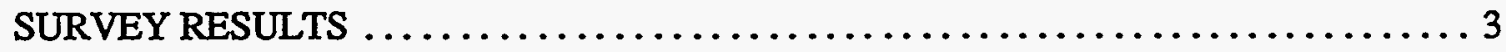

RADIATION MEASUREMENTS $\ldots \ldots \ldots \ldots \ldots \ldots \ldots \ldots \ldots \ldots \ldots \ldots \ldots$

SAMPLE RESULTS $\ldots \ldots \ldots \ldots \ldots \ldots \ldots \ldots \ldots \ldots \ldots \ldots \ldots \ldots \ldots \ldots, \ldots \ldots \ldots$

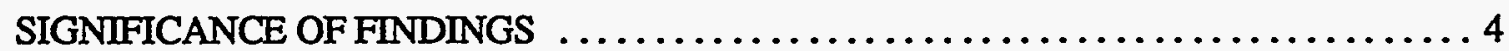

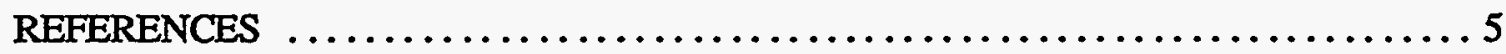




\section{LIST OF FIGURES}

1 Diagram showing the general location of Oxford, Ohio $\ldots \ldots \ldots \ldots \ldots \ldots \ldots 6$

2 Diagram showing the location of the former Alba Craft Laboratory (ACL) in the City of Oxford, Ohio . . . . . . . . . . . . . . . . . . . . . . . . 7

3 Diagram of the ACL site showing the foundation line of the former building and the grid established for referencing data locations $\ldots \ldots \ldots \ldots \ldots \ldots \ldots \ldots 8$

4 Diagram showing the locations of most systematic samples collected at the ACL ... 9

5 Diagram showing locations of samples VS241, VS242, and VS243 collected over the sewer line between the comer of the former ACL building and the residential property to the northeast $\ldots \ldots \ldots \ldots \ldots \ldots \ldots \ldots \ldots \ldots \ldots, 10$

6 Enlargement (from Fig. 4) showing locations of systematic samples collected at the north end of the ACL property from N20 to N50 $\ldots \ldots \ldots \ldots \ldots \ldots \ldots \ldots . .11$

7 Enlargement (from Fig. 4) showing locations of systematic samples collected at the south end of the ACL property from S20 to $\sim \mathrm{N} 18 \ldots \ldots \ldots \ldots \ldots \ldots \ldots \ldots \ldots$

8 Diagram showing locations of biased samples collected on the ACL property $\ldots \ldots \ldots 13$

\section{LIST OF TABLES}

1 Applicable guidelines for protection against radiation $\ldots \ldots \ldots \ldots \ldots \ldots \ldots \ldots, 14$

2 Background radiation levels for the Oxford, Ohio, area $\ldots \ldots \ldots \ldots \ldots \ldots \ldots \ldots$

3 Radionuclide concentrations in soil samples collected at the former ACL,

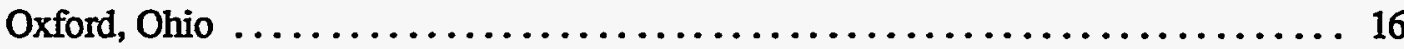





\section{ACKNOWLEDGMENTS}

This project was sponsored by the Office of Environmental Restoration, U.S. Department of Energy, under contract DE-AC05-960R22464 with Lockheed Martin Energy Research Corp. The authors wish to acknowledge the essential contributions of J. F. Allred, G. H. Cofer, R. C. Gosslee, R. A. Mathis, S. P. McKenzie, D. D. McKinney, V. P. Patania, R. E. Rodriguez, D. A. Roberts, D. A. Rose, P. F. Tiner, and W. Winton of the Measurement Applications and Development Group, Health Sciences Research Division, Oak Ridge National Laboratory, for their participation in collecting, reporting, and analyzing the data for this effort. The surveying assistance of A. C. Butler and the graphics skills of J. M. Lovegrove of Midwest Technical, Inc., are also gratefully acknowledged. 


\begin{abstract}
Between October 1952 and February 1957, National Lead of Ohio (NLO), a primary contractor for the Atomic Energy Commission (AEC), subcontracted certain uranium machining operations to Alba Craft Laboratory, Incorporated, located at 10-14 West Rose Avenue, Oxford, Ohio. In 1992, personnel from Oak Ridge National Laboratory (ORNL) confirmed the presence of residual radioactive materials from the AEC-related operations in and around the facility in amounts exceeding the applicable Department of Energy (DOE) guidelines.
\end{abstract}

Although the amount of uranium found on the property posed little health hazard if left undisturbed, the levels were sufficient to require remediation to bring radiological conditions into compliance with current guidelines, thus ensuring that the public and the environment are protected. The Remedial Action Contractor for these properties was Bechtel National, Incorporated (BNI).

DOE requires that verification of completed cleanup work at DOE Formerly Utilized Sites Remedial Action Program (FUSRAP) sites such as this shall be performed and documented by an Independent Verification Contractor. The objective of verification activities is to certify that the remedial action reduced contamination levels to within authorized limits.

A team from ORNL conducted a radiological verification survey of the former Alba Craft Laboratory property between December 1994 and February 1995. The survey was conducted at the request of DOE and included directly measured radiation levels, the collection and analysis of soil samples to determine concentrations of uranium and certain other radionuclides, and comparison of these data to the guidelines. This document reports the findings of this survey.

The results of the independent verification survey of the former Alba Craft Laboratory property demonstrate that all contaminated areas have been remediated to radionuclide concentrations and activity levels below the applicable guideline limits set by DOE. 



\section{Results of the Independent Radiological Verification Survey of the Remedial Action Performed at the Former Alba Craft Laboratory Site, Oxford, Ohio (OXO001)}

\section{INTRODUCTION}

During the approximate time period between October 1952 and February 1957, National Lead of Ohio (NLO), a primary contractor for the Atomic Energy Commission (AEC), subcontracted certain uranium machining operations to Alba Craft Laboratory, Incorporated, Oxford, Ohio. The facility, located at 10-14 West Rose Avenue, also housed operations in 1954 involving NLO personnel and NLO uranium material. It is not known how much material was machined at the site by NLO in 1954, but the total quantity of uranium machined by Alba Craft is estimated at several hundred tons. Figures 1 and 2 show the relative location of the City of Oxford in southwestern Ohio and the location of the property in Oxford.

Early investigations of the Alba Craft property had disclosed evidence of residual radioactive materials from the AEC-related operations at the site. At the request of the Department of Energy (DOE) under the Formerly Utilized Sites Remedial Action Program (FUSRAP), a radiological assessment was conducted in 1992 by personnel from Oak Ridge National Laboratory (ORNL) to locate and define the extent of the contamination on the site itself, and to determine whether any of these materials had migrated off-site. ${ }^{*}$ The results of that survey confirmed the presence of residual radioactive material from the AEC-related operations in and around the Alba Craft facility in amounts exceeding the applicable DOE guidelines (Table 1).1 Although the amount of uranium found posed little health hazard if left undisturbed, the levels were sufficient to require cleanup action to bring the property into compliance with current guidelines, thereby ensuring that the public and the environment are protected.

DOE's Environmental Restoration Program dictates that independent verification (IV) of completed cleanup work at DOE FUSRAP sites shall be performed and documented according to prescribed procedures prior to certification of the property for release for unrestricted use.2,3 The objective of verification activities is to confirm that the remedial action reduced contamination levels to within authorized limits.

As the designated Independent Verification Contractor (IVC) for this site, ORNL's Measurement Applications and Development Group was assigned to validate the remedial action and restoration activities conducted by the Remedial Action Contractor, Bechtel National, Incorporated (BNI). At the time of the verification survey, the building had been completely razed, and the majority of the dismantled remains had been removed off-site. Figure 3 is a diagram indicating the former location of the Alba Craft Laboratory building and showing the grid established by BNI during the remedial activities to enable precise location of measurements and samples.

"The survey was performed by members of the Measurement Applications and Development Group, Health Sciences Research Division, Oak Ridge National Laboratory under DOE contract DE-AC05960R22464 with Lockheed Martin Energy Research Corp. 


\section{SCOPE OF THE SURVEY}

The outdoor survey of the property included:

- A gamma scan near the ground surface over $100 \%$ of the property.

- Collection of systematic surface and subsurface soil samples.

- Collection of biased surface soil samples.

- Measurements of gamma radiation levels at $1 \mathrm{~m}$ at soil sample locations.

- Selected beta-gamma scanning at suspect areas such as locations of former doors.

- On-site field screening with a portable gamma spectrometer to estimate uranium concentrations in soil samples.

- Measurements of radiation levels and sampling of drains, sewerlines, and areas downstream from Alba Craft gutter drains.

\section{SURVEY METHODS}

Descriptions of the typical methods and instrumentation providing guidance for this survey are given in Procedures Manual for the ORNL Radiological Survey Activities (RASA) Program, ORNL/TM-8600, April 1987, and in Measurement Applications and Development Group Guidelines, ORNL-6782, January 1995.4,5

\section{SURFACE RADIATION MEASUREMENTS}

Gamma radiation levels were determined using a portable NaI gamma scintillation meter. Because NaI gamma scintillators are energy dependent, measurements of gamma radiation levels in counts per minute (cpm) are normalized to pressurized ionization chamber (PIC) measurements to estimate gamma exposure rates in $\mu \mathrm{R} / \mathrm{h}$. Using a Geiger-Mueller pancake detector, betagamma radiation levels were measured in counts per minute (cpm) over selected soil surfaces to detect areas of elevated activity. The measurements were then converted to dose rates (mrad/h) and/or disintegrations per minute over $100 \mathrm{~cm}^{2}\left(\mathrm{dpm} / 100 \mathrm{~cm}^{2}\right)$ for comparison with guideline values.

\section{SAMPLING AND ANALYSES}

Systematic surface (0- to $15-\mathrm{cm})$ soil samples were collected outdoors in all remediated areas at selected locations without regard to radiation levels (e.g., at grid points). Systematic samples were also collected at locations surrounding anomalies to define the boundaries of detectable contamination, and repeatedly at locations where remediation was incomplete. Where appropriate, subsurface soil samples were taken at these locations at increments of $15 \mathrm{~cm}$ below the surface to determine the completeness of cleanup. Biased soil samples were taken at locations of anomalous gamma or beta-gamma radiation levels. 
A portable gamma spectrometer was used on-site in conjunction with beta-gamma measurements as a screening device to provide an immediate estimate of uranium content (pCi/g) in the field using the freshly collected soil samples. The reliability of the field screening method was established at another site by comparison of the field-estimated uranium concentration in a specific sample to the results found from later laboratory analysis of that same sample. When the comparisons proved to be dependable, the field screening method was relied upon to provide the basis for an immediate decision on further action. Cleanup could then be instituted immediately and followed promptly by the verification survey. The approach was conservative in that the maximum uranium concentration resulting from multiple field analyses performed on a single sample was selected for comparison with the site-specific $238 \mathrm{U}$ guideline. The process of drying, weighing, grinding, and homogenizing samples according to the required QA procedures was performed in the laboratory at a later time as confirmation of radionuclide concentrations.

\section{SURVEY RESULTS}

Current DOE guidelines for FUSRAP sites are summarized in Table 1; the derived sitespecific guideline for $238 \mathrm{U}$ is also listed. ${ }^{6}$ Typical background radiation levels for the Oxford, Ohio, area are presented in Table 2 . These data are provided for comparison with the survey results presented in this report. Gamma radiation levels are reported in gross $\mu \mathrm{R} / \mathrm{h}$. Background concentrations have not been subtracted from radionuclide concentrations in soil, debris, or other materials.

\section{RADIATION MEASUREMENTS}

Verification activities began on December 6, 1994, when BNI notified ORNL that two of the grid blocks were ready for confirmation. The verification survey continued through February of 1995. Following remediation, gamma exposure rate measurements over the entire property ranged from 4 to $6 \mu \mathrm{R} / \mathrm{h}$, values well below guidelines and less than the typical range of exposure rates for the Oxford area (Table 1).

\section{SAMPLE RESULTS}

Locations of soil sample collection are shown on Figs. 4 through 8. Figures 4 and 5 show the locations of all the systematic soil samples. Samples VS41 through VS43 (Fig. 5) were collected from surface soil over a storm drain leading from the former Alba Craft building to a common city pipeline north of the curb at S. Main Street. The path of the pipeline ran beneath a garage attached to the residential property just northeast of and adjoining the Alba Craft property.

Sampling of several remediated areas led ORNL to request that BNI repeat the excavation. In the process of re-excavating these areas, previously sampled uncontaminated soil was removed along with contaminated soil. These locations were necessarily sampled a second time. The initial samples were collected at the original soil surface and the later samples were taken from newly exposed surface soil. This occurred at locations $0 \mathrm{~N}, 0 \mathrm{E}, 20 \mathrm{~N}, 16 \mathrm{E}, 45 \mathrm{~N}, 20 \mathrm{E}$, and $20 \mathrm{~N}, 20 \mathrm{E}$ for 
samples VS44 and VS81, VS7 and VS191, VS63 and VS184, VS203 and VS229. For instance, sample VS44 was collected prior to excavation; VS81 was collected later from the new surface soil at the bottom of the trench that BNI dug to excavate the drainline from the NE comer of the Alba Craft site. Sample VS7 was the original surface soil sample; VS191 was collected later to verify the additional remediation. Figures 6 and 7 are enlargements of the north and south portions of Fig. 4. Figure 8 displays the locations of biased samples. Table 3 details the results of soil analysis.

Concentrations of $226 \mathrm{Ra}$ in all samples were within the range of typical background values with a maximum concentration of $1.2 \mathrm{pCi} / \mathrm{g}$ (Tables 1 and 3). Concentrations of 232Th were generally within the range of typical background values with the exception of 8 samples. Those samples exceeded that highest background concentration $(0.99 \mathrm{pCi} / \mathrm{g}$, Table 1$)$ with a maximum of $2.2 \mathrm{pCi} / \mathrm{g}$. However, concentrations of 226Ra and 232Th are well within the guideline values in all samples.

The results of laboratory analysis of systematic soil samples taken from all excavated areas demonstrate final concentrations of $238 \mathrm{U}$ ranging from 0.83 to $53 \mathrm{pCi} / \mathrm{g}$ (Table 3). Seventeen systematic samples contained concentrations of $238 \mathrm{U}$ exceeding the derived guideline of $17.5 \mathrm{pCi} / \mathrm{g}$ (Table 2). Elevated concentrations of $238 \mathrm{U}$ ranging from 22 to $73 \mathrm{pCi} / \mathrm{g}$ were found in 4 of 6 biased samples. However, averaging the results of the elevated samples along with the results of others collected within each immediate $100-\mathrm{m}^{2}$ area results in an average value that meets the guideline in every case.

\section{SIGNIFICANCE OF FINDINGS}

The results of the independent verification survey of the former Alba Craft Laboratory property demonstrate that all contaminated areas have been remediated to radionuclide concentrations and activity levels below the applicable guidelines for unrestricted use set by DOE. 


\section{REFERENCES}

1. M. E. Murray, K. S. Brown, and R. A. Mathis, Results of the Radiological Survey at the Former Alba Craft Laboratory Site Properties, Oxford, Ohio (OXO001), ORNL/RASA92/14, Martin Marietta Energy Systems, Oak Ridge Natl. Lab., March 1993.

2. R. P. Whitfield, Deputy Assistant Secretary for Environmental Restoration, U.S. DOE, memorandum to J. J. Fiore, Director, Office of Eastern Area Programs, Office of Environmental Restoration, U.S. DOE, May 6, 1992.

3. Verification and Certification Protocol-Supplement No. 2 to the FUSRAP Summary Protocol, Rev. 1, U.S. DOE, Office of Nuclear Energy, Division of Facility and Site Decommissioning Projects, November 1985.

4. Procedures Manual for the ORNL Radiological Survey Activities (RASA) Program, ORNL/TM-8600, Martin Marietta Energy Systems, Inc., Oak Ridge Natl. Lab., April 1987.

5. Measurement Applications and Development Group Guidelines, ORNL-6782, Martin Marietta Energy Systems, Oak Ridge, Natl. Lab., January 1995.

6. W. A. Williams, Designation and Certification Manager, Division of Off-Site Programs, Office of Eastern Area Programs, Office of Environmental Restoration, U.S. Department of Energy, memorandum, "Uranium Guidelines for the Alba Craft Site, Oxford, Ohio, to L. K. Price, Director, Former Sites Restoration Division, Oak Ridge Field Office, U.S. Department of Energy, 
ORNL-DWG 92-9817

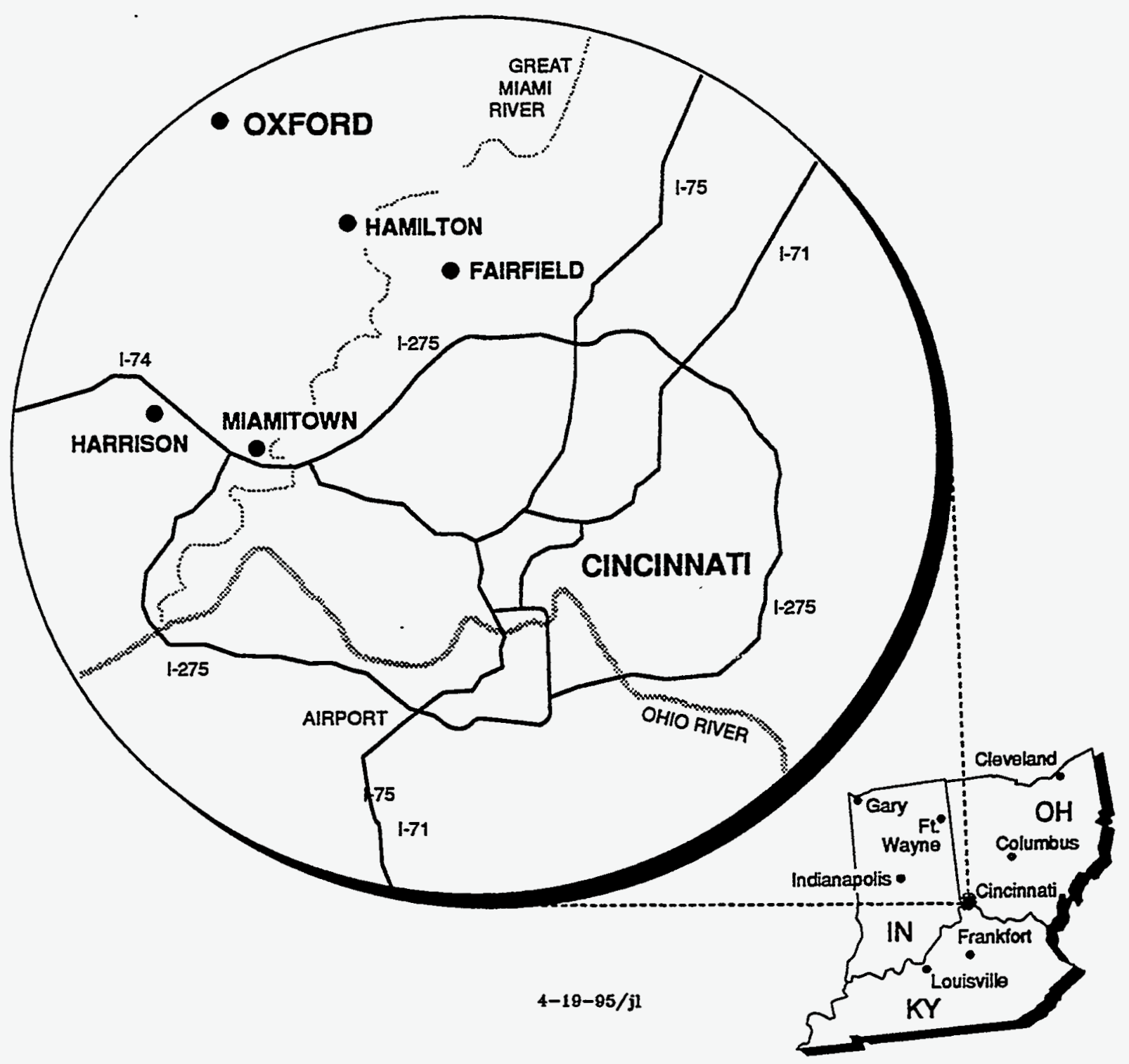

Fig. 1. Diagram showing the general location of Oxford, Ohio. 


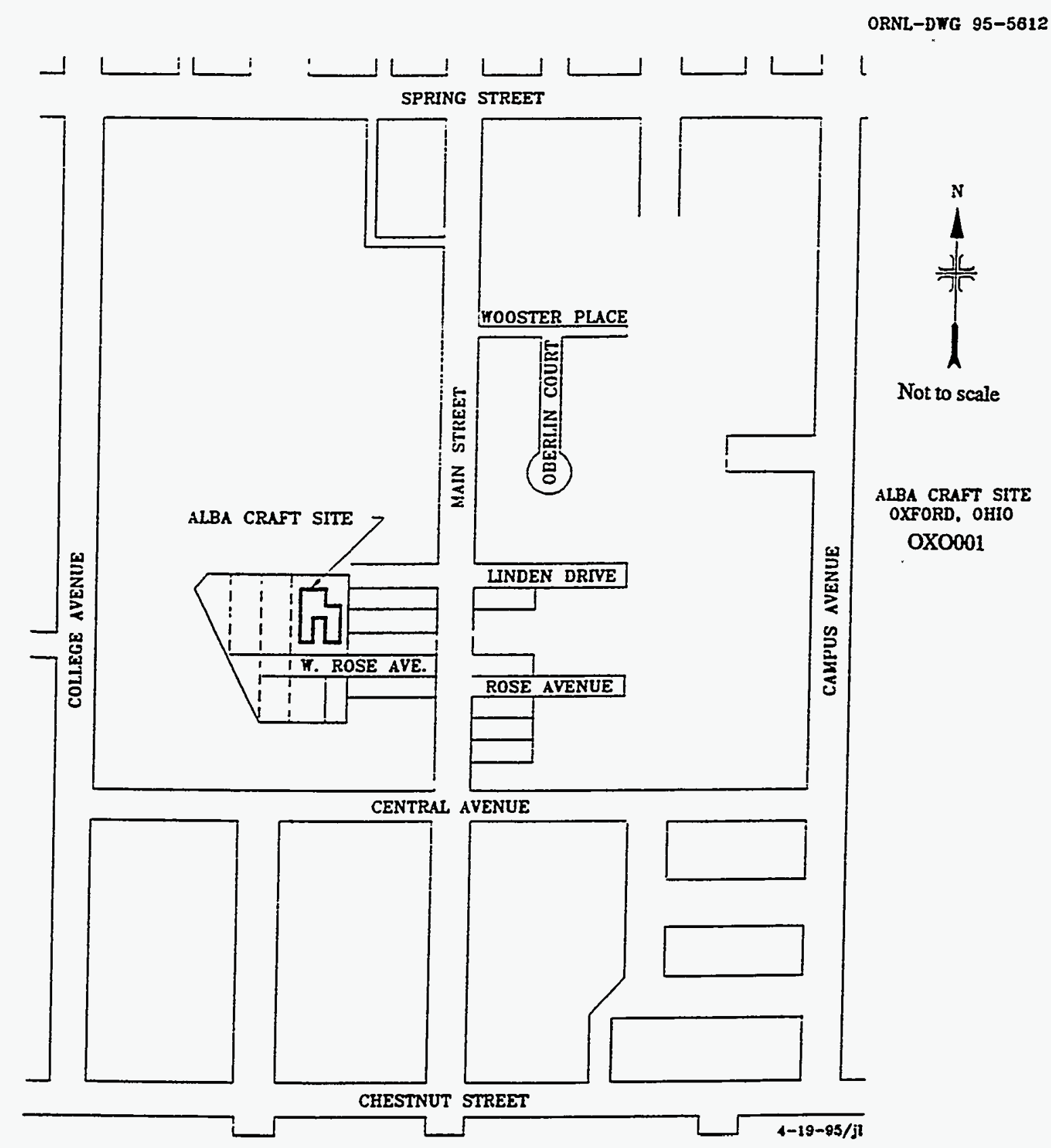

Fig. 2. Diagram showing the general location of the Alba Craft site, Oxford, Ohio. 

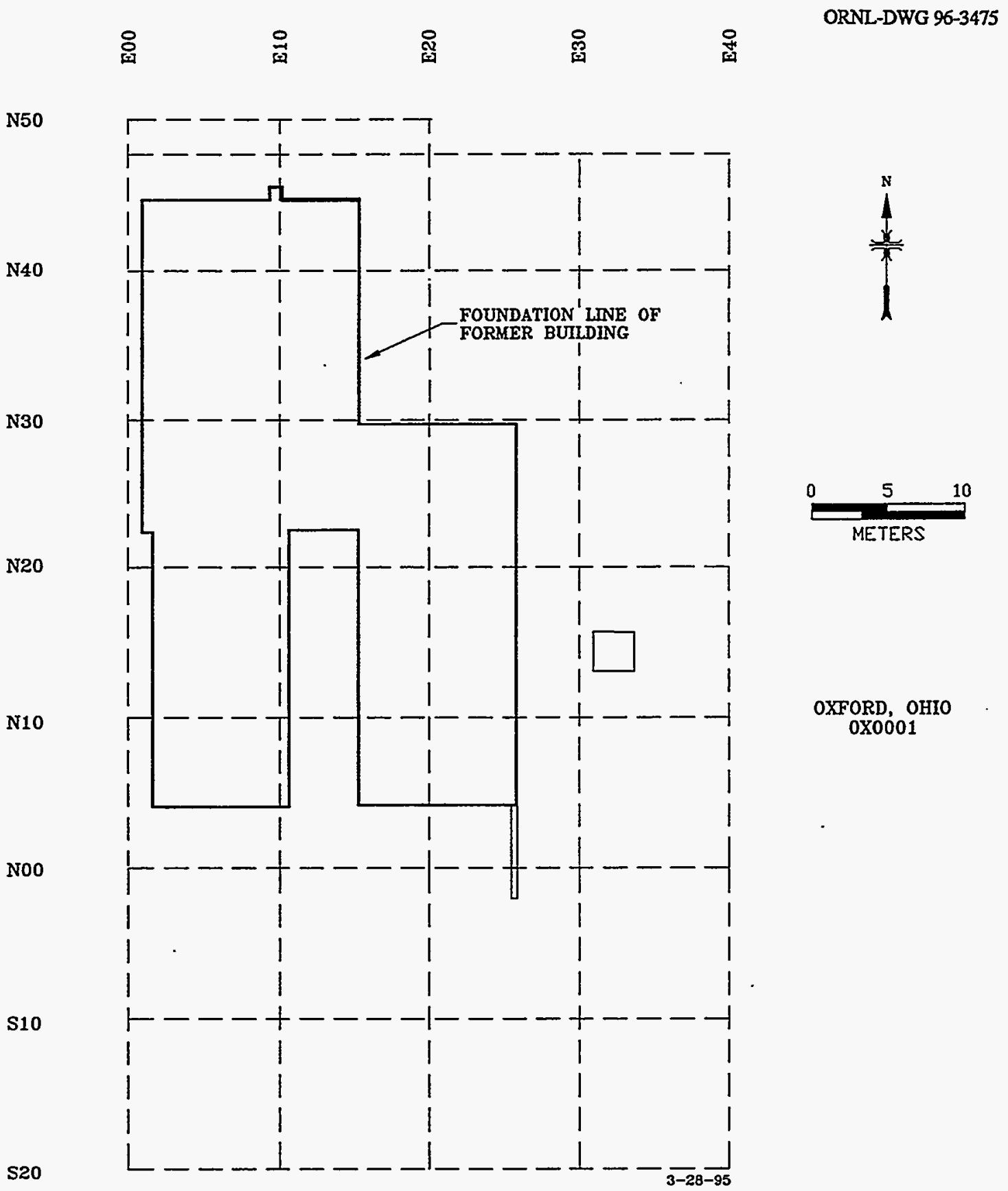

Fig. 3. Diagram of the ACL site showing the foundation line of the former building and the grid established for referencing data locations. 


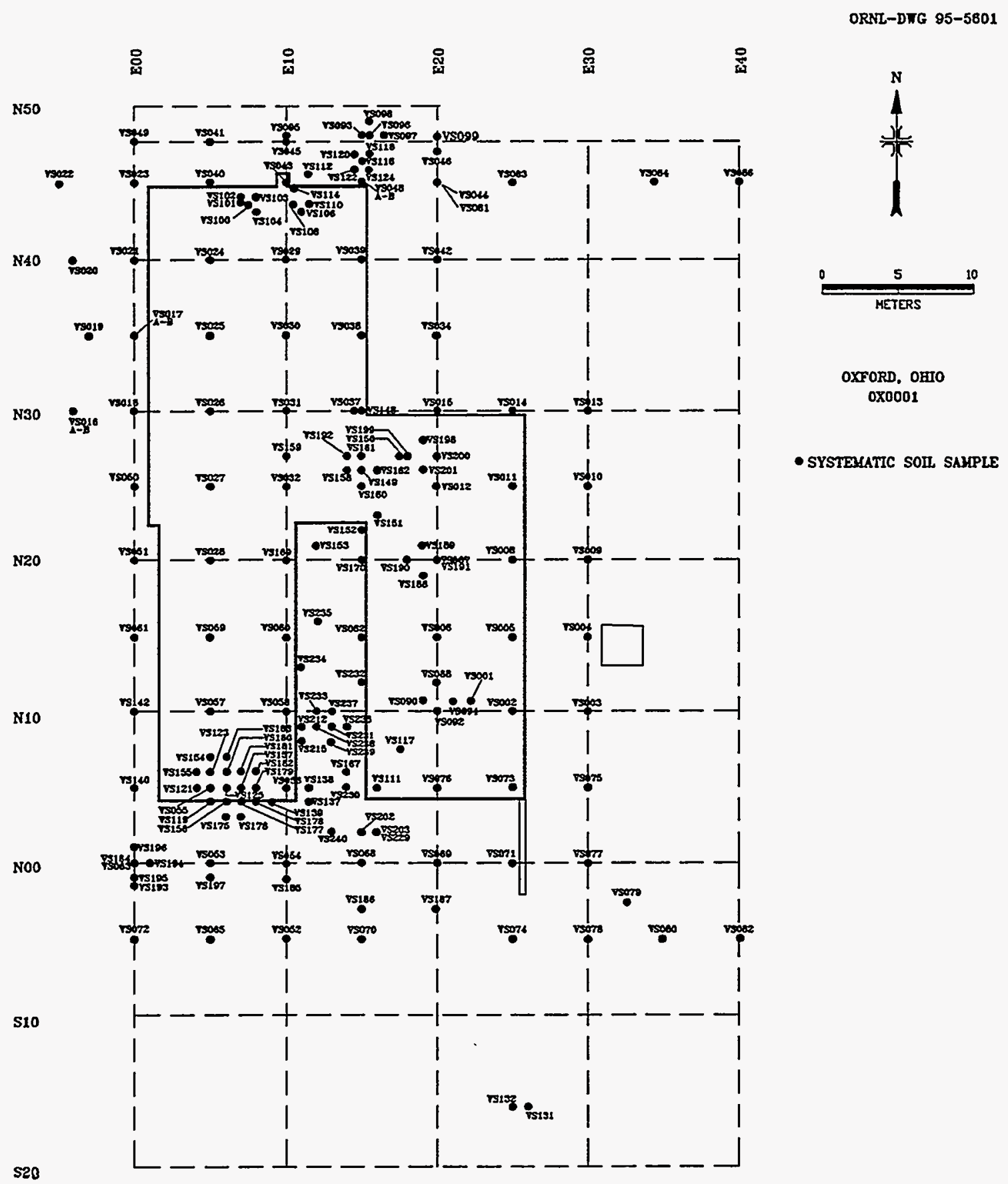

Fig. 4. Diagram showing the locations of most systematic samples collected at the ACL. 


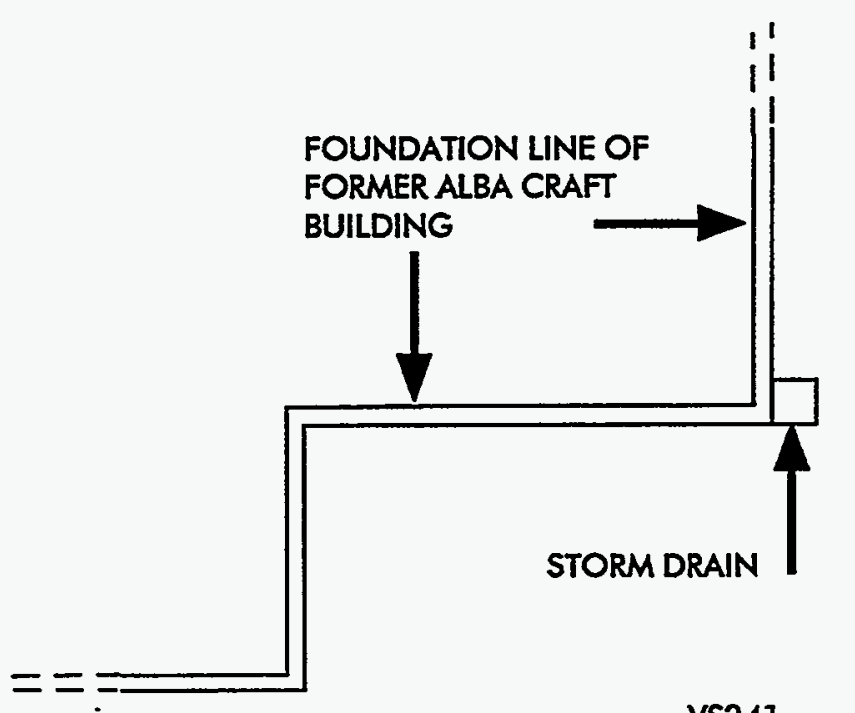

- VS241
ORNL-DWG 95-5615R

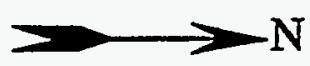

FEET

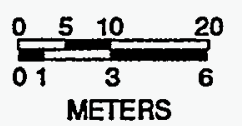

OXFORD, OHIO

OX0001

- SOIL SAMPLE

ZZ CONCRETE

- VS242

STORM DRAIN

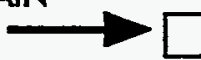

- VS243

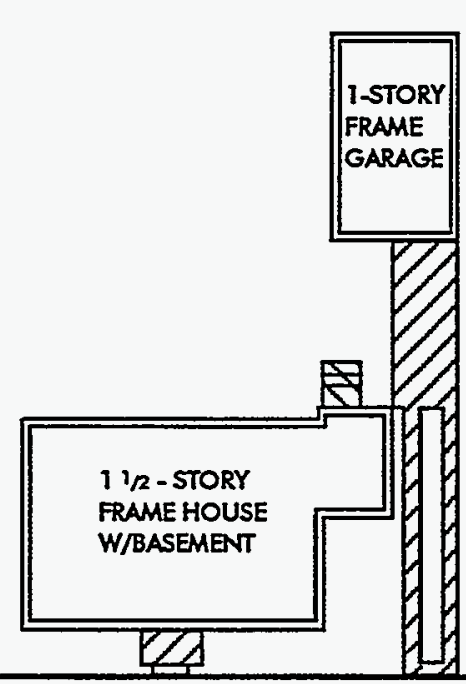

MAIN STREET

7-37-96/ffe

Fig. 5. Diagram showing locations of samples VS241, VS242, and VS243 collected over the sewer line between the corner of the former ACL building and the residential property to the northeast. 
ORNL-DWG 95-5602

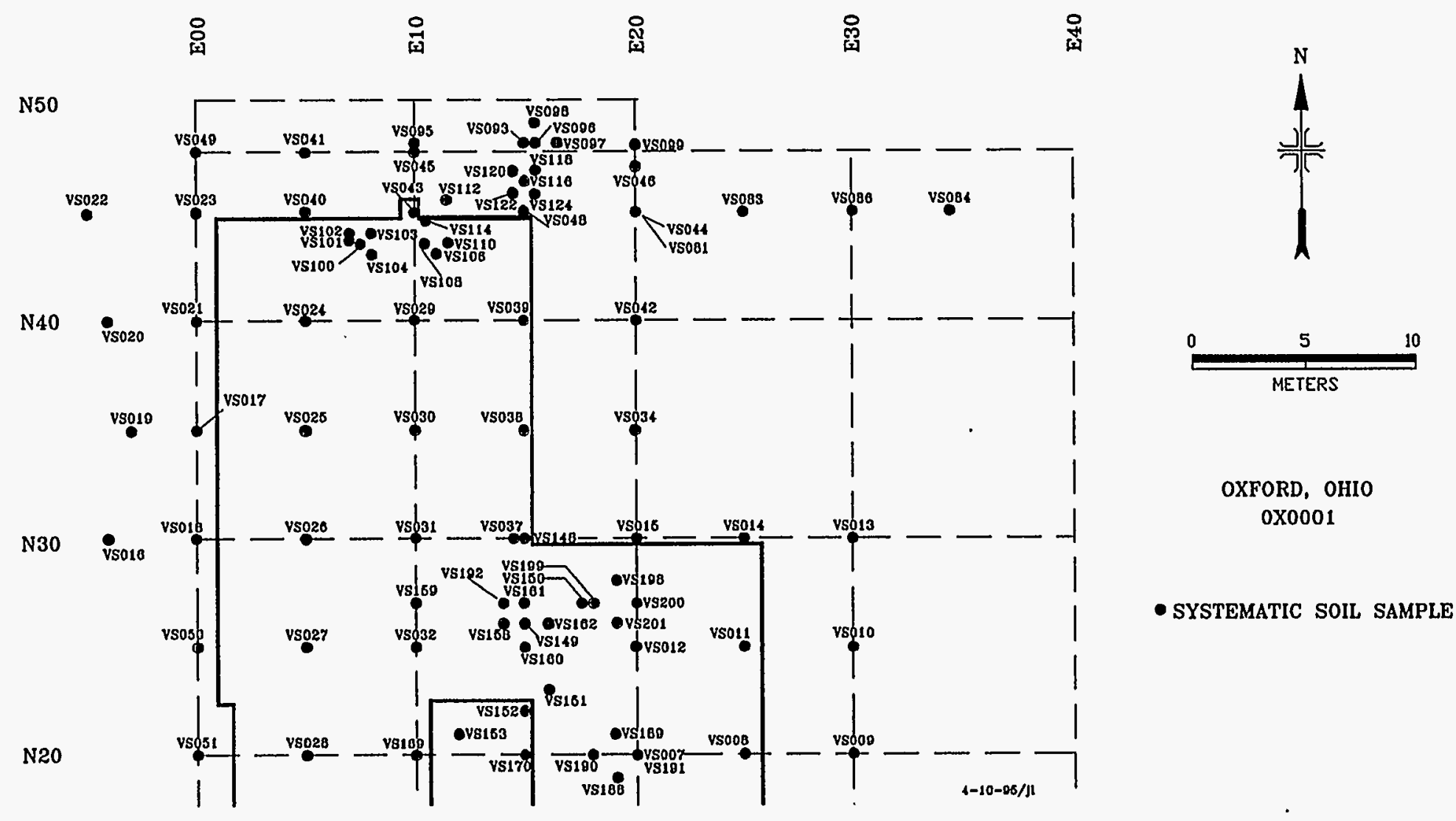

Fig. 6. Enlargement (from Fig. 4) showing locations of systematic samples collected at the north end of the ACL property from N20 to N50. 


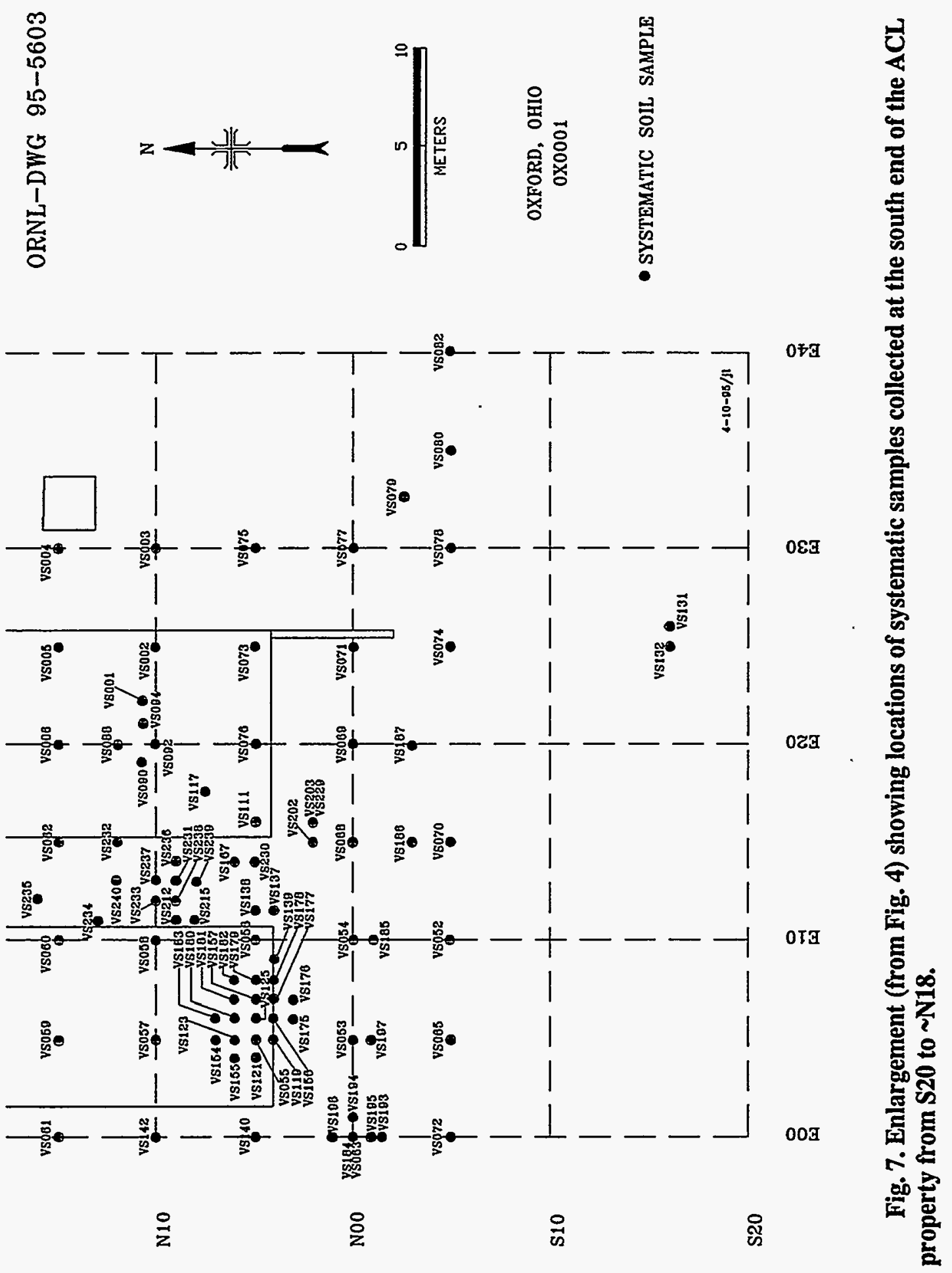



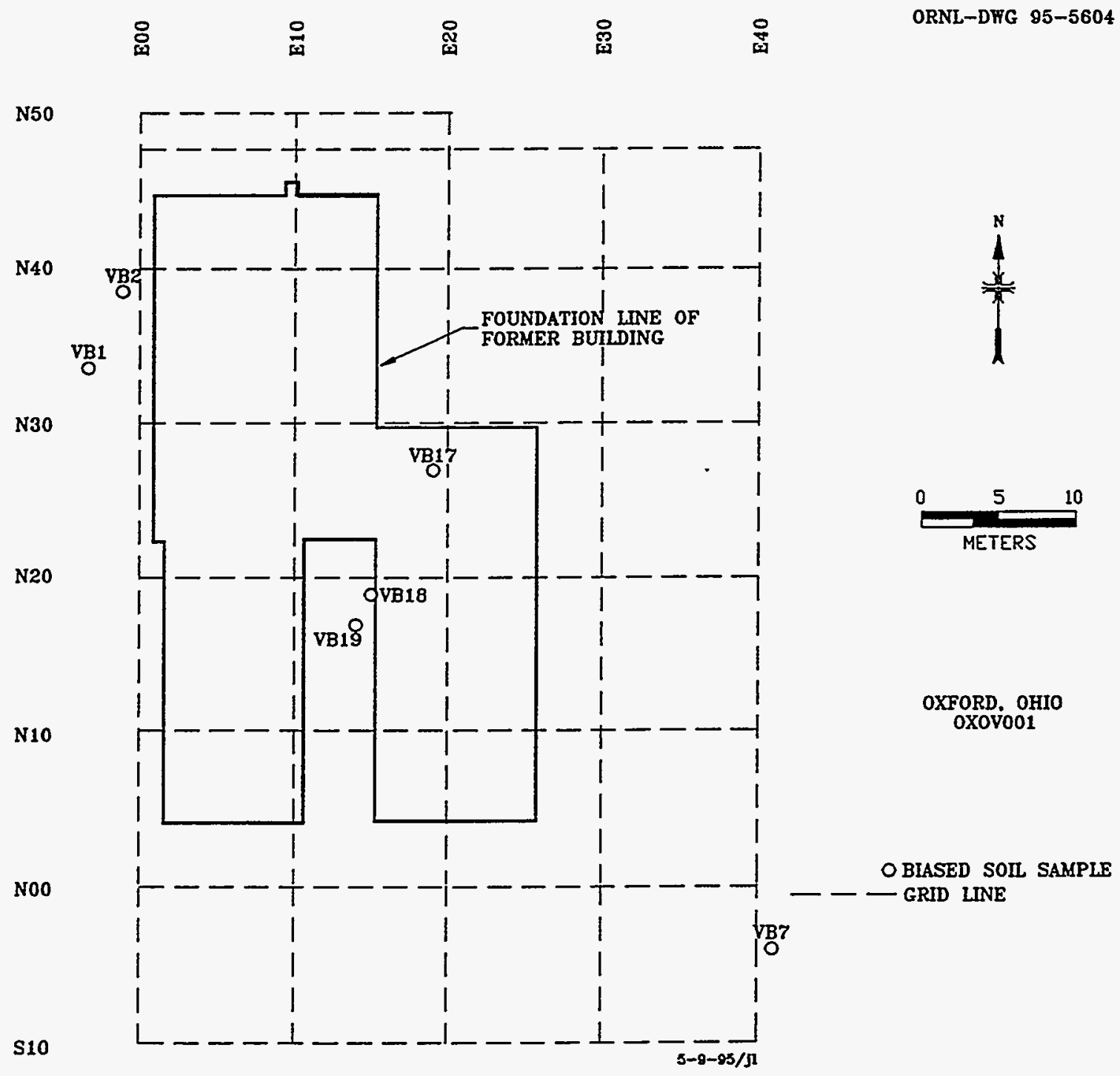

Fig. 8. Diagram showing locations of biased samples collected on the ACL property. 
Table 1. Applicable guidelines for protection against radiation (Limits for uncontrolled areas)

\begin{tabular}{|c|c|c|}
\hline Mode of exposure & Exposure conditions & Guideline value \\
\hline Gamma radiation & $\begin{array}{l}\text { Indoor gamma radiation level } \\
\text { (above background) }\end{array}$ & $20 \mu \mathrm{R} / \mathrm{h}^{a}$ \\
\hline \multirow[t]{3}{*}{$\begin{array}{l}\text { Total residual surface } \\
\text { contamination } b\end{array}$} & $\begin{array}{l}\text { 238U,235U, U-natural (alpha } \\
\text { emitters) } \\
\text { or } \\
\text { Beta-gamma emittersc } \\
\text { Fixed and removable } \\
\text { Average } \\
\text { Removable }\end{array}$ & $\begin{array}{r}15,000 \mathrm{dpm} / 100 \mathrm{~cm} 2 \\
5,000 \mathrm{dpm} / 100 \mathrm{~cm} 2 \\
1,000 \mathrm{dpm} / 100 \mathrm{~cm} 2\end{array}$ \\
\hline & $\begin{array}{l}\text { 232Th, Th-natural (alpha } \\
\text { emitters) } \\
\text { or } \\
\text { 90Sr (beta-gamma emitter) } \\
\text { Fixed and removable } \\
\text { Average } \\
\text { Removable }\end{array}$ & $\begin{array}{r}3,000 \mathrm{dpm} / 100 \mathrm{~cm}^{2} \\
1,000 \mathrm{dpm} / 100 \mathrm{~cm}^{2} \\
200 \mathrm{dpm} / 100 \mathrm{~cm}^{2}\end{array}$ \\
\hline & $\begin{array}{l}\text { 226Ra, 230Th, transuranics } \\
\text { Fixed and removable } \\
\text { Average } \\
\text { Removable }\end{array}$ & $\begin{array}{r}300 \mathrm{dpm} / 100 \mathrm{~cm}^{2} \\
100 \mathrm{dpm} / 100 \mathrm{~cm}^{2} \\
20 \mathrm{dpm} / 100 \mathrm{~cm}^{2}\end{array}$ \\
\hline $\begin{array}{l}\text { Beta-gamma dose } \\
\text { rates }\end{array}$ & $\begin{array}{l}\text { Surface dose rate averaged } \\
\text { over not more than } 1 \mathrm{~m}^{2}\end{array}$ & $0.20 \mathrm{mrad} / \mathrm{h}$ \\
\hline & $\begin{array}{l}\text { Maximum dose rate in any } \\
100-\mathrm{cm}^{2} \text { area }\end{array}$ & $1.0 \mathrm{mrad} / \mathrm{h}$ \\
\hline $\begin{array}{l}\text { Radionuclide con- } \\
\text { centrations in soil } \\
\text { (generic) }\end{array}$ & $\begin{array}{l}\text { Maximum permissible con- } \\
\text { centration of the following } \\
\text { radionuclides in soil above } \\
\text { background levels, averaged } \\
\text { over a } 100-\mathrm{m}^{2} \text { area } \\
226 \mathrm{Ra} \\
232 \mathrm{Th} \\
230 \mathrm{Th}\end{array}$ & $\begin{array}{l}5 \mathrm{pCi} / \mathrm{g} \text { averaged over the } \\
\text { first } 15 \mathrm{~cm} \text { of soil below } \\
\text { the surface; } 15 \mathrm{pCi} / \mathrm{g} \text { when } \\
\text { averaged over } 15-\mathrm{cm} \text {-thick } \\
\text { soil layers more than } 15 \mathrm{~cm} \\
\text { below the surface }\end{array}$ \\
\hline Derived concentrations & $238 \mathrm{U}$ & $17.5 \mathrm{pCi} / \mathrm{g}^{d}$ \\
\hline 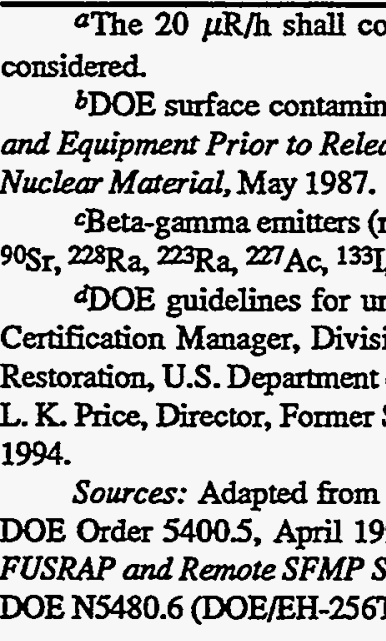 & $\begin{array}{l}\text { with the basic dose limit (100 mr } \\
\text { guidelines are consistent with NRC } \\
\text { Unrestricted Use or Termination of } \\
\text { uclides with decay modes other than } \\
125 \text { I. } \\
1 \text { are derived on a site-specific basi } \\
\text { Off-Site Programs, Office of Easte } \\
\text { ergy, memorandum "Uranium Guidel } \\
\text { Restoration Division, Oak Ridge Fiel } \\
\text { Department of Energy, Radiation P } \\
\text { d U.S. Department of Energy, Guid } \\
\text { Rev. 2, March 1987; and U.S. Depart } \\
\text { le 1992. }\end{array}$ & $\begin{array}{l}\text { When an appropriate-use scenario is } \\
\text { es for Decontamination at Facilities } \\
\text { s for By-Product, Source, or Special } \\
\text { ission or spontaneous fission) except } \\
\text { : W. A. Williams, Designation and } \\
\text { Programs, Office of Environmental } \\
\text { he Alba Craft Site, Oxford, Ohio," to } \\
\text { U.S. Department of Energy, July 15, } \\
\text { of the Public and the Environment, } \\
\text { in Residual Radioactive Material at } \\
\text { inergy Radiological Control Manual, }\end{array}$ \\
\hline
\end{tabular}


Table 2. Background radiation levels and concentrations of selected radionuclides in soil samples taken near

Oxford, Ohio

\begin{tabular}{|c|c|c|}
\hline \multirow{2}{*}{$\begin{array}{c}\text { Type of radiation measurement } \\
\text { or sample }\end{array}$} & \multicolumn{2}{|c|}{$\begin{array}{l}\text { Radiation level or radionuclide } \\
\text { concentration }\end{array}$} \\
\hline & Range & Average \\
\hline $\begin{array}{l}\text { Gamma exposure rate at } 1 \mathrm{~m} \text { above } \\
\text { ground surface }(\mu \mathrm{R} / \mathrm{h})^{a}\end{array}$ & $6-9$ & 8 \\
\hline $\begin{array}{l}\text { Concentration of radionuclides } \\
\text { in soil (pCi/g dry wt) }\end{array}$ & & \\
\hline $\begin{array}{l}238 \mathrm{U} \\
226 \mathrm{Ra} \\
232 \mathrm{Th}\end{array}$ & $\begin{array}{l}0.86-2.2 \\
1.0-2.5 \\
0.71-0.99\end{array}$ & $\begin{array}{l}1.3 \\
1.9 \\
0.89\end{array}$ \\
\hline
\end{tabular}

aResults of measurements taken at three locations near Oxford, Ohio.

$b$ Results of analysis of soil samples obtained from three locations near Oxford, Ohio.

Source: T. E. Myrick, B. A. Berven, and F. F. Haywood, State Background Measurements Taken During 1975-1979, ORNL/TM-7343, November, 1981. 
Table 3. Results of radionuclide analysis of soil samples collected from the former Alba Craft Laboratory property, Oxford, Ohio

\begin{tabular}{|c|c|c|c|c|c|c|}
\hline \multirow{3}{*}{$\begin{array}{c}\text { Sample } \\
\text { I.D. }\end{array}$} & \multirow{3}{*}{$\begin{array}{c}\text { Grid } \\
\text { location } b\end{array}$} & \multirow{3}{*}{$\begin{array}{l}\text { Depth } \\
(\mathrm{cm})\end{array}$} & \multicolumn{4}{|c|}{ Radionuclide concentration $(\mathrm{pCi} / \mathrm{g})^{a}$} \\
\hline & & & \multicolumn{2}{|c|}{$238 \mathrm{Uc}$} & \multirow[b]{2}{*}{$226 \mathrm{Ra}$} & \multirow[b]{2}{*}{ 232Th } \\
\hline & & & Field & $\overline{\mathrm{Lab}}$ & & \\
\hline \multicolumn{7}{|c|}{ Systematic samplesd } \\
\hline VS1 & $10.75 \mathrm{~N}, 22.2 \mathrm{E}$ & $0-15$ & 37 & $3.7 \pm 0.85$ & $0.87 \pm 0.07$ & $0.60 \pm 0.09$ \\
\hline VS2 & $10 \mathrm{~N}, 25 \mathrm{E}$ & $0-15$ & $e$ & $2.2 \pm 0.27$ & $0.78 \pm 0.07$ & $0.59 \pm 0.09$ \\
\hline VS3 & $10 \mathrm{~N}, 30 \mathrm{E}$ & $0-15$ & 0.7 & $1.2 \pm 0.32$ & $1.1 \pm 0.08$ & $0.85 \pm 0.11$ \\
\hline VS4 & $15 \mathrm{~N}, 30 \mathrm{E}$ & $0-15$ & 4.7 & $3.7 \pm 0.38$ & $1.2 \pm 0.08$ & $0.92 \pm 0.14$ \\
\hline VS5 & $15 \mathrm{~N}, 25 \mathrm{E}$ & $0-15$ & $e$ & $2.0 \pm 0.29$ & $0.93 \pm 0.07$ & $0.63 \pm 0.10$ \\
\hline VS6 & $15 \mathrm{~N}, 20 \mathrm{E}$ & $0-15$ & 0.7 & $2.6 \pm 0.78$ & $1.1 \pm 0.08$ & $0.97 \pm 0.12$ \\
\hline VS7 & $20 \mathrm{~N}, 20 \mathrm{E}$ & $0-15$ & 10 & $1.7 \pm 0.34$ & $0.61 \pm 0.05$ & $0.38 \pm 0.08$ \\
\hline VS8 & $20 \mathrm{~N}, 25 \mathrm{E}$ & $0-15$ & $e$ & $4.3 \pm 0.81$ & $0.83 \pm 0.06$ & $0.51 \pm 0.09$ \\
\hline VS9 & $20 \mathrm{~N}, 30 \mathrm{E}$ & $0-15$ & $e$ & $1.7 \pm 0.80$ & $1.2 \pm 0.09$ & $1.1 \pm 0.14$ \\
\hline VS10 & $25 \mathrm{~N}, 30 \mathrm{E}$ & $0-15$ & 12 & $16 \pm 1.1$ & $1.2 \pm 0.08$ & $0.99 \pm 0.14$ \\
\hline VS11 & $25 \mathrm{~N}, 25 \mathrm{E}$ & $0-15$ & 1.8 & $2.9 \pm 0.56$ & $0.77 \pm 0.06$ & $0.52 \pm 0.10$ \\
\hline VS12 & $25 \mathrm{~N}, 20 \mathrm{E}$ & $0-15$ & $e$ & $2.1 \pm 0.30$ & $0.54 \pm 0.05$ & $0.31 \pm 0.06$ \\
\hline VS13 & $30 \mathrm{~N}, 30 \mathrm{E}$ & $0-15$ & 1.2 & $2.2 \pm 0.32$ & $1.2 \pm 0.09$ & $1.0 \pm 0.12$ \\
\hline VS14 & $30 \mathrm{~N}, 25 \mathrm{E}$ & $0-15$ & 0.8 & $3.3 \pm 0.32$ & $0.94 \pm 0.07$ & $0.70 \pm 0.11$ \\
\hline VS15 & $30 \mathrm{~N}, 20 \mathrm{E}$ & $0-15$ & 1.6 & $2.7 \pm 0.33$ & $0.96 \pm 0.07$ & $0.70 \pm 0.10$ \\
\hline VS16A & $30 \mathrm{~N}, 4.3 \mathrm{~W}$ & $0-15$ & 5.5 & $2.5 \pm 0.57$ & $1.4 \pm 0.09$ & $0.86 \pm 0.13$ \\
\hline VS16B & $30 \mathrm{~N}, 4.3 \mathrm{~W}$ & $15-30$ & 4.7 & $1.4 \pm 0.40$ & $1.5 \pm 0.08$ & $1.0 \pm 0.13$ \\
\hline VS17A & $35 \mathrm{~N}, 0 \mathrm{E}$ & $0-15$ & 6.2 & $4.0 \pm 1.5$ & $1.3 \pm 0.08$ & $0.92 \pm 0.14$ \\
\hline VS17B & $35 \mathrm{~N}, 0 \mathrm{E}$ & $15-30$ & 7.3 & $4.3 \pm 0.50$ & $1.3 \pm 0.09$ & $1.0 \pm 0.13$ \\
\hline VS18 & $30 \mathrm{~N}, 0 \mathrm{E}$ & $0-15$ & $e$ & $2.4 \pm 0.37$ & $0.94 \pm 0.19$ & $0.50 \pm 0.14$ \\
\hline VS19 & $35 N, 3 W$ & $0-15$ & $e$ & $1.2 \pm 0.25$ & $0.65 \pm 0.15$ & $0.40 \pm 0.15$ \\
\hline VS20 & $40 N, 4 W$ & $0-15$ & $e$ & $1.6 \pm 0.30$ & $0.95 \pm 0.18$ & $0.70 \pm 0.20$ \\
\hline VS21 & $40 \mathrm{~N}, 0 \mathrm{E}$ & $0-15$ & 13 & $18 \pm 0.95$ & $1.0 \pm 0.20$ & $0.70 \pm 0.20$ \\
\hline VS22 & $45 \mathrm{~N}, 5 \mathrm{~W}$ & $0-15$ & $e$ & $2.3 \pm 0.35$ & $0.90 \pm 0.15$ & $0.70 \pm 0.20$ \\
\hline VS23 & $45 \mathrm{~N}, 0 \mathrm{E}$ & $0-15$ & 1.7 & $1.9 \pm 0.32$ & $1.0 \pm 0.21$ & $0.58 \pm 0.07$ \\
\hline VS24 & $40 \mathrm{~N}, 5 \mathrm{E}$ & $0-15$ & 4.4 & $2.1 \pm 0.50$ & $0.80 \pm 0.25$ & $0.59 \pm 0.10$ \\
\hline VS25 & $35 \mathrm{~N}, 5 \mathrm{E}$ & $0-15$ & 2.9 & $1.8 \pm 0.42$ & $0.78 \pm 0.24$ & $0.79 \pm 0.25$ \\
\hline VS26 & $30 \mathrm{~N}, 5 \mathrm{E}$ & $0-15$ & 5.3 & $2.5 \pm 0.36$ & $1.0 \pm 0.20$ & $0.88 \pm 0.20$ \\
\hline VS27 & $25 \mathrm{~N}, 5 \mathrm{E}$ & $0-15$ & 7.4 & $4.4 \pm 0.48$ & $1.1 \pm 0.20$ & $0.79 \pm 0.18$ \\
\hline
\end{tabular}


Table 3. (continued)

\begin{tabular}{|c|c|c|c|c|c|c|}
\hline \multirow{3}{*}{$\begin{array}{c}\text { Sample } \\
\text { I.D. }\end{array}$} & \multirow{3}{*}{$\begin{array}{c}\text { Grid } \\
\text { location } b\end{array}$} & \multirow{3}{*}{$\begin{array}{l}\text { Depth } \\
\text { (cm) }\end{array}$} & \multicolumn{4}{|c|}{ Radionuclide concentration(pCi/g)a } \\
\hline & & & \multicolumn{2}{|c|}{$238 \mathrm{Uc}$} & \multirow[b]{2}{*}{$226 \mathrm{Ra}$} & \multirow[b]{2}{*}{$232 \mathrm{Th}$} \\
\hline & & & Field & $\overline{\mathrm{Lab}}$ & & \\
\hline VS28 & $20 \mathrm{~N}, 5 \mathrm{E}$ & $0-15$ & $e$ & $2.0 \pm 0.30$ & $0.68 \pm 0.15$ & $0.26 \pm 0.09$ \\
\hline VS29 & $40 \mathrm{~N}, 10 \mathrm{E}$ & $0-15$ & 4.1 & $2.1 \pm 0.34$ & $1.1 \pm 0.21$ & $0.96 \pm 0.21$ \\
\hline VS30 & $35 \mathrm{~N}, 10 \mathrm{E}$ & $0-15$ & 5 & $1.8 \pm 0.32$ & $1.1 \pm 0.21$ & $0.64 \pm 0.17$ \\
\hline VS31 & $30 \mathrm{~N}, 10 \mathrm{E}$ & $0-15$ & 5.4 & $2.0 \pm 0.33$ & $1.2 \pm 0.21$ & $0.82 \pm 0.19$ \\
\hline VS32 & $25 \mathrm{~N}, 10 \mathrm{E}$ & $0-15$ & 3.1 & $1.9 \pm 0.31$ & $1.2 \pm 0.21$ & $0.80 \pm 0.18$ \\
\hline VS34 & $35 \mathrm{~N}, 20 \mathrm{E}$ & $0-15$ & 4.5 & $1.8 \pm 0.30$ & $1.1 \pm 0.19$ & $0.47 \pm 0.13$ \\
\hline VS37 & $30 \mathrm{~N}, 14.5 \mathrm{E}$ & $0-15$ & 6.1 & $4.2 \pm 0.67$ & $0.98 \pm 0.27$ & $0.86 \pm 0.28$ \\
\hline VS38 & $35 \mathrm{~N}, 15 \mathrm{E}$ & $0-15$ & 9 & $6.7 \pm 0.77$ & $0.99 \pm 0.20$ & $0.83 \pm 0.16$ \\
\hline VS39 & $40 \mathrm{~N}, 15 \mathrm{E}$ & $0-15$ & 4.6 & $4.1 \pm 0.42$ & $0.67 \pm 0.14$ & $0.57 \pm 0.15$ \\
\hline VS40 & $45 \mathrm{~N}, 5 \mathrm{E}$ & $0-15$ & 11 & $11 \pm 0.70$ & $1.0 \pm 0.14$ & $0.77 \pm 0.11$ \\
\hline VS41 & $47.7 \mathrm{~N}, 5 \mathrm{E}$ & $0-15$ & 15 & $13 \pm 1.0$ & $0.96 \pm 0.19$ & $1.1 \pm 0.18$ \\
\hline VS42 & $40 \mathrm{~N}, 20 \mathrm{E}$ & $0-15$ & 4.6 & $1.9 \pm 0.44$ & $0.93 \pm 0.26$ & $0.89 \pm 0.29$ \\
\hline VS43 & $45 \mathrm{~N}, 10 \mathrm{E}$ & $0-15$ & 11 & $7.9 \pm 0.88$ & $1.2 \pm 0.29$ & $0.61 \pm 0.23$ \\
\hline VS44 & $45 \mathrm{~N}, 20 \mathrm{E}$ & $0-15$ & 15 & $19 \pm 1.4$ & $0.87 \pm 0.20$ & $0.72 \pm 0.17$ \\
\hline VS45 & $47.7 \mathrm{~N}, 10 \mathrm{E}$ & $0-15$ & 2.4 & $1.9 \pm 0.34$ & $0.57 \pm 0.15$ & $0.25 \pm 0.09$ \\
\hline VS46 & $47 \mathrm{~N}, 20 \mathrm{E}$ & $0-15$ & 5.8 & $4.3 \pm 0.55$ & $0.91 \pm 0.21$ & $0.50 \pm 0.17$ \\
\hline VS48A & $45 \mathrm{~N}, 15 \mathrm{E}$ & $0-15$ & 2.1 & $5.4 \pm 0.60$ & $0.90 \pm 0.15$ & $0.56 \pm 0.11$ \\
\hline VS48B & $45 \mathrm{~N}, 15 \mathrm{E}$ & $15-30$ & 10 & $12 \pm 0.82$ & $1.1 \pm 0.21$ & $0.51 \pm 0.16$ \\
\hline VS49 & $47.7 \mathrm{~N}, 0 \mathrm{E}$ & $0-15$ & 3.6 & $3.4 \pm 0.49$ & $1.0 \pm 0.17$ & $0.77 \pm 0.13$ \\
\hline VS50 & $25 \mathrm{~N}, 0 \mathrm{E}$ & $0-15$ & 5.4 & $1.4 \pm 0.30$ & $0.98 \pm 0.16$ & $0.77 \pm 0.12$ \\
\hline VS51 & $20 \mathrm{~N}, 0 \mathrm{E}$ & $0-15$ & 2.8 & $2.4 \pm 0.37$ & $0.88 \pm 0.19$ & $0.37 \pm 0.12$ \\
\hline VS52 & $5 S, 10 E$ & $0-15$ & $e$ & $0.95 \pm 0.21$ & $0.50 \pm 0.09$ & $0.36 \pm 0.07$ \\
\hline VS53 & $0 \mathrm{~N}, 5 \mathrm{E}$ & $0-15$ & $e$ & $4.2 \pm 0.50$ & $0.61 \pm 0.16$ & $0.29 \pm 0.12$ \\
\hline VS54 & $O N, 10 E$ & $0-15$ & 4.4 & $6.9 \pm 0.68$ & $1.1 \pm 0.17$ & $0.87 \pm 0.14$ \\
\hline VS55 & $5 \mathrm{~N}, 5 \mathrm{E}$ & $0-15$ & 26 & $21 \pm 1.1$ & $0.75 \pm 0.17$ & $0.58 \pm 0.16$ \\
\hline VS56 & $5 \mathrm{~N}, 10 \mathrm{E}$ & $0-15$ & 8.6 & $6.0 \pm 0.62$ & $1.0 \pm 0.21$ & $0.59 \pm 0.18$ \\
\hline VS57 & $10 \mathrm{~N}, 5 \mathrm{E}$ & $0-15$ & 3 & $7.4 \pm 0.73$ & $1.0 \pm 0.17$ & $0.87 \pm 0.14$ \\
\hline VS58 & $10 \mathrm{~N}, 10 \mathrm{E}$ & $0-15$ & 8 & $11 \pm 1.4$ & $0.92 \pm 0.14$ & $0.92 \pm 0.13$ \\
\hline VS59 & $15 \mathrm{~N}, 5 \mathrm{E}$ & $0-15$ & $e$ & $1.3 \pm 0.29$ & $0.76 \pm 0.13$ & $0.45 \pm 0.10$ \\
\hline VS60 & $15 \mathrm{~N}, 10 \mathrm{E}$ & $0-15$ & $e$ & $1.6 \pm 0.29$ & $0.65 \pm 0.16$ & $0.34 \pm 0.13$ \\
\hline VS61 & $15 \mathrm{~N}, 0 \mathrm{E}$ & $0-15$ & $e$ & $3.8 \pm 0.61$ & $0.93 \pm 0.25$ & $0.65 \pm 0.24$ \\
\hline VS62 & $15 \mathrm{~N}, 15 \mathrm{E}$ & $0-15$ & 8.1 & $7.1 \pm 0.77$ & $0.70 \pm 0.16$ & $0.78 \pm 0.16$ \\
\hline
\end{tabular}




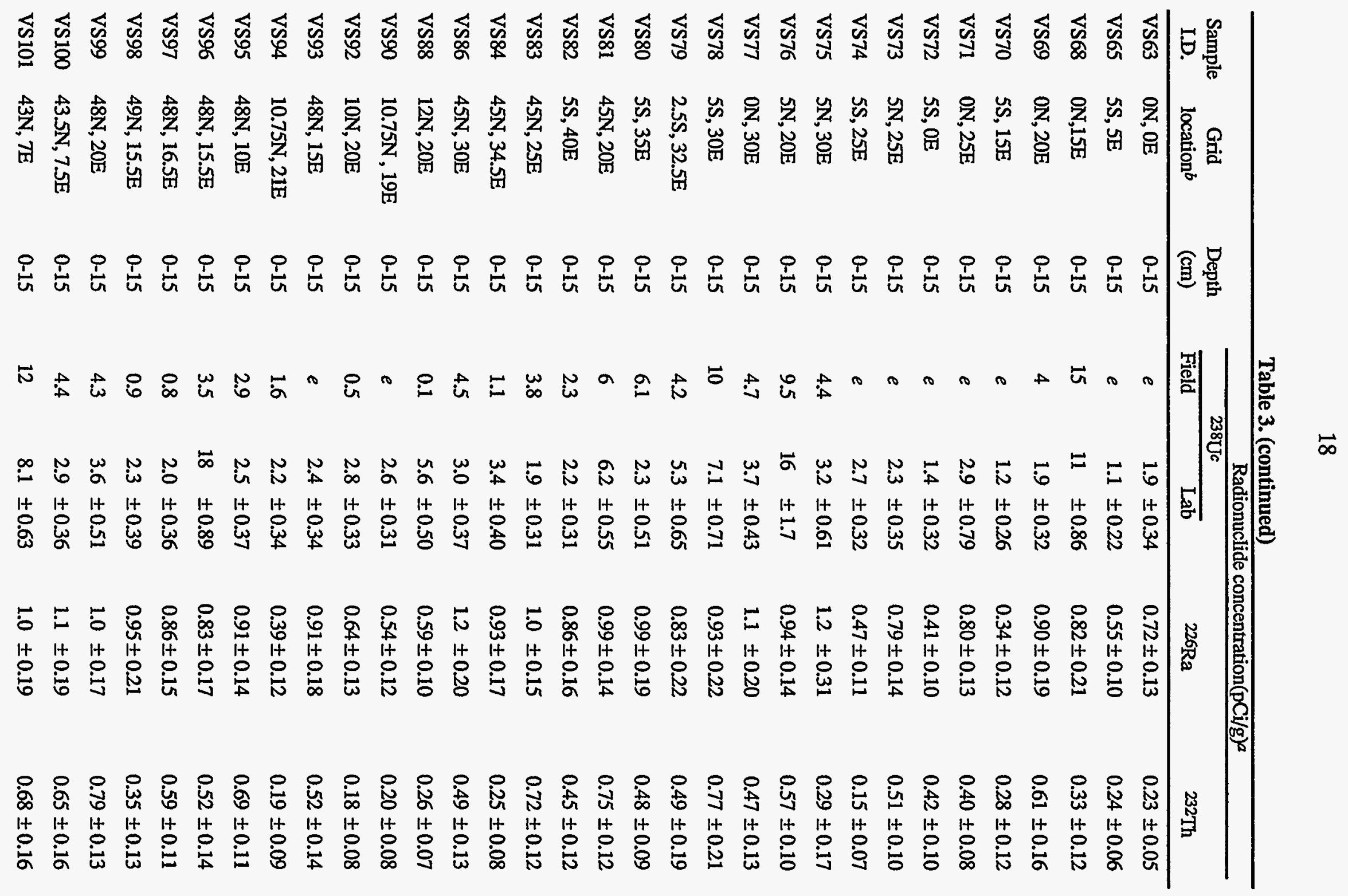


Table 3. (continued)

\begin{tabular}{|c|c|c|c|c|c|c|c|}
\hline \multirow{3}{*}{$\begin{array}{l}\text { Sample } \\
\text { I.D. }\end{array}$} & \multirow{3}{*}{$\begin{array}{c}\text { Grid } \\
\text { location } b\end{array}$} & \multirow{3}{*}{$\begin{array}{l}\text { Depth } \\
(\mathrm{cm})\end{array}$} & \multicolumn{5}{|c|}{ Radionuclide concentration $(\mathrm{pC} / \mathrm{g})^{a}$} \\
\hline & & & \multicolumn{3}{|c|}{$238 \mathrm{Uc}$} & \multirow[b]{2}{*}{$226 \mathrm{Ra}$} & \multirow[b]{2}{*}{ 232Th } \\
\hline & & & Field & & $\overline{a b}$ & & \\
\hline VS102 & $44 \mathrm{~N}, 7 \mathrm{E}$ & $0-15$ & 17 & 16 & \pm 1.1 & $1.1 \pm 0.20$ & $0.98 \pm 0.16$ \\
\hline VS103 & $44 \mathrm{~N}, 8 \mathrm{E}$ & $0-15$ & 45 & 27 & \pm 1.2 & $0.93 \pm 0.16$ & $0.47 \pm 0.07$ \\
\hline VS104 & $43 \mathrm{~N}, 8 \mathrm{E}$ & $0-15$ & 6.8 & 7.0 & \pm 0.62 & $1.1 \pm 0.16$ & $0.46 \pm 0.08$ \\
\hline VS106 & $44 \mathrm{~N}, 11 \mathrm{E}$ & $0-15$ & 21 & 24 & \pm 1.1 & $1.1 \pm 0.19$ & $0.79 \pm 0.18$ \\
\hline VS108 & $43.5 \mathrm{~N}, 10.5 \mathrm{E}$ & $0-15$ & 17 & 16 & \pm 0.84 & $0.87 \pm 0.17$ & $0.45 \pm 0.12$ \\
\hline VS110 & $43.5 \mathrm{~N}, 11.5 \mathrm{E}$ & $0-15$ & 20 & 22 & \pm 1.0 & $1.1 \pm 0.19$ & $0.43 \pm 0.13$ \\
\hline VS111 & $5 \mathrm{~N}, 16 \mathrm{E}$ & $0-15$ & 4.2 & 5.9 & \pm 0.58 & $0.81 \pm 0.13$ & $0.71 \pm 0.12$ \\
\hline VS112 & $44.5 \mathrm{~N}, 11.5 \mathrm{E}$ & $0-15$ & 18 & 9.5 & \pm 0.71 & $0.81 \pm 0.13$ & $0.51 \pm 0.10$ \\
\hline VS114 & $44.5 \mathrm{~N}, 10.5 \mathrm{E}$ & $0-15$ & 7.7 & 7.3 & \pm 0.62 & $1.2 \pm 0.16$ & $0.58 \pm 0.10$ \\
\hline VS116 & $46.3 \mathrm{~N}, 15 \mathrm{E}$ & $0-15$ & $\dot{7}$ & 6.8 & \pm 0.60 & $1.2 \pm 0.16$ & $0.80 \pm 0.12$ \\
\hline VS117 & $7.5 \mathrm{~N}, 17.5 \mathrm{E}$ & $0-15$ & 2 & 5.4 & \pm 0.99 & $0.85 \pm 0.13$ & $0.55 \pm 0.09$ \\
\hline VS118 & $46.8 \mathrm{~N}, 15.5 \mathrm{E}$ & $0-15$ & 2 & 2.3 & \pm 0.32 & $0.86 \pm 0.16$ & $0.39 \pm 0.11$ \\
\hline VS119 & $4 \mathrm{~N}, 5 \mathrm{E}$ & $0-15$ & 10 & 9.7 & \pm 0.62 & $0.74 \pm 0.15$ & $0.33 \pm 0.10$ \\
\hline VS120 & $46.8 \mathrm{~N}, 14.5 \mathrm{E}$ & $0-15$ & $e$ & 1.4 & \pm 0.24 & $0.76 \pm 0.15$ & $0.19 \pm 0.07$ \\
\hline VS121 & $5 \mathrm{~N}, 4 \mathrm{E}$ & $0-15$ & $e$ & 4.5 & \pm 1.0 & $0.88 \pm 0.16$ & $0.50 \pm 0.11$ \\
\hline VS122 & $45.8 \mathrm{~N}, 14.5 \mathrm{E}$ & $0-15$ & 37 & 45 & \pm 10 & $1.2 \pm 0.17$ & $0.45 \pm 0.08$ \\
\hline VS123 & $6 \mathrm{~N}, 5 \mathrm{E}$ & $0-15$ & 36 & 24 & \pm 1.1 & $0.77 \pm 0.12$ & $0.34 \pm 0.06$ \\
\hline VS124 & $45.8 \mathrm{~N}, 15.5 \mathrm{E}$ & $0-15$ & 14 & 13 & \pm 1.0 & $1.1 \pm 0.20$ & $0.92 \pm 0.16$ \\
\hline VS125 & $5 \mathrm{~N}, 6 \mathrm{E}$ & $0-15$ & 45 & 34 & \pm 1.3 & $0.90 \pm 0.18$ & $0.56 \pm 0.13$ \\
\hline VS131 & $16 \mathrm{~S}, 26 \mathrm{E}$ & $0-15$ & 9.3 & 12 & \pm 0.79 & $1.1 \pm 0.20$ & $0.41 \pm 0.11$ \\
\hline VS132 & $16 \mathrm{~S}, 25 \mathrm{E}$ & $0-15$ & 6 & 10 & \pm 0.76 & $1.1 \pm 0.16$ & $0.68 \pm 0.12$ \\
\hline VS137 & $4 \mathrm{~N}, 11.5 \mathrm{E}$ & $0-15$ & 1.3 & 6.2 & \pm 0.54 & $0.78 \pm 0.12$ & $0.27 \pm 0.05$ \\
\hline VS138 & $5 \mathrm{~N}, 11.8 \mathrm{E}$ & $0-15$ & 7.5 & 14 & \pm 0.84 & $0.63 \pm 0.17$ & $0.19 \pm 0.11$ \\
\hline VS139 & $4 \mathrm{~N}, 9.8 \mathrm{E}$ & $0-15$ & 5.3 & 11 & \pm 0.78 & $0.91 \pm 0.14$ & $0.60 \pm 0.10$ \\
\hline VS140 & $5 \mathrm{~N}, 0 \mathrm{E}$ & $0-15$ & $e$ & 2.1 & \pm 0.46 & $0.86 \pm 0.18$ & $0.60 \pm 0.12$ \\
\hline VS142 & $10 \mathrm{~N}, 0 \mathrm{E}$ & $0-15$ & $e$ & 1.9 & \pm 0.38 & $0.82 \pm 0.15$ & $0.53 \pm 0.10$ \\
\hline VS148 & $30 \mathrm{~N}, 15 \mathrm{E}$ & $0-15$ & 8.5 & 6.3 & \pm 0.71 & $0.52 \pm 0.17$ & $0.34 \pm 0.16$ \\
\hline VS149 & $20 \mathrm{~N}, 15 \mathrm{E}$ & $0-15$ & 21 & 22 & \pm 1.3 & $0.82 \pm 0.22$ & $0.37 \pm 0.18$ \\
\hline VS150 & $27 \mathrm{~N}, 17.5 \mathrm{E}$ & $0-15$ & 13 & 13 & \pm 0.92 & $0.85 \pm 0.17$ & $0.69 \pm 0.13$ \\
\hline VS151 & $23 \mathrm{~N}, 16 \mathrm{E}$ & $0-15$ & 2.3 & 2.7 & \pm 0.22 & $0.70 \pm 0.10$ & $0.56 \pm 0.09$ \\
\hline VS152 & $22 \mathrm{~N}, 15 \mathrm{E}$ & $0-15$ & 8.7 & 6.8 & \pm 0.83 & $0.92 \pm 0.27$ & $0.29 \pm 0.06$ \\
\hline VS153 & $21 \mathrm{~N}, 12 \mathrm{E}$ & $0-15$ & $e$ & 1.3 & \pm 0.34 & $0.79 \pm 0.19$ & $0.31 \pm 0.15$ \\
\hline
\end{tabular}


Table 3. (continued)

\begin{tabular}{|c|c|c|c|c|c|c|c|}
\hline \multirow{2}{*}{$\begin{array}{l}\text { Sample } \\
\text { I.D. }\end{array}$} & \multirow{2}{*}{$\begin{array}{c}\text { Grid } \\
\text { location } b\end{array}$} & \multirow{2}{*}{$\begin{array}{l}\text { Depth } \\
(\mathrm{cm})\end{array}$} & \multicolumn{5}{|c|}{ Radionuclide concentration $(\mathrm{pCi} / \mathrm{g})^{a}$} \\
\hline & & & Field & & $\overline{a g}$ & $226 \mathrm{Ra}$ & $232 \mathrm{Th}$ \\
\hline VS154 & $\mathrm{TN}, 5 \mathrm{E}$ & $0-15$ & 1.5 & 2.5 & \pm 0.45 & $0.68 \pm 0.20$ & $0.41 \pm 0.17$ \\
\hline VS155 & $\curvearrowleft \mathrm{N}, 4 \mathrm{E}$ & $0-15$ & $e$ & 7.9 & \pm 0.62 & $0.65 \pm 0.13$ & $0.56 \pm 0.11$ \\
\hline VS156 & $4 \mathrm{~N}, 6 \mathrm{E}$ & $0-15$ & 62 & 42 & \pm 1.7 & $0.89 \pm 0.22$ & $0.20 \pm 0.12$ \\
\hline V157A & $5 \mathrm{~N}, 7 \mathrm{E}$ & $0-15$ & 49 & 35 & \pm 2.3 & $0.92 \pm 0.25$ & $0.71 \pm 0.19$ \\
\hline V157B & $5 \mathrm{~N}, 7 \mathrm{E}$ & $15-30$ & 31 & 15 & \pm 2.0 & $1.2 \pm 0.24$ & $2.2 \pm 0.24$ \\
\hline VS158 & $26 \mathrm{~N}, 14 \mathrm{E}$ & $0-15$ & 12 & 5.9 & \pm 0.50 & $0.82 \pm 0.16$ & $0.31 \pm 0.12$ \\
\hline VS159 & $27 \mathrm{~N}, 10 \mathrm{E}$ & $0-15$ & 2.2 & 1.4 & \pm 0.37 & $0.80 \pm 0.22$ & $0.62 \pm 0.20$ \\
\hline VS160 & $25 \mathrm{~N}, 15 \mathrm{E}$ & $0-15$ & 14 & 5.6 & \pm 0.53 & $0.74 \pm 0.17$ & $0.34 \pm 0.14$ \\
\hline VS161 & $27 \mathrm{~N}, 15 \mathrm{E}$ & $0-15$ & 6.4 & 4.9 & \pm 0.50 & $0.83 \pm 0.17$ & $0.52 \pm 0.15$ \\
\hline VS162 & $2 \curvearrowleft \mathrm{N}, 16 \mathrm{E}$ & $0-15$ & 4 & 2.1 & \pm 0.43 & $0.94 \pm 0.17$ & $0.95 \pm 0.14$ \\
\hline VS167 & $6 \mathrm{~N}, 14 \mathrm{E}$ & $0-15$ & 3.4 & 3.7 & \pm 0.42 & $0.80 \pm 0.17$ & $0.39 \pm 0.13$ \\
\hline VS169 & $20 \mathrm{~N}, 10 \mathrm{E}$ & $0-15$ & 9 & 4.0 & \pm 0.47 & $0.78 \pm 0.14$ & $0.32 \pm 0.06$ \\
\hline VS170 & $20 \mathrm{~N}, 15 \mathrm{E}$ & $0-15$ & 4.3 & 2.1 & \pm 0.39 & $0.90 \pm 0.16$ & $0.78 \pm 0.12$ \\
\hline VS175 & $3 \mathrm{~N}, 6 \mathrm{E}$ & $0-15$ & 5.4 & 8.2 & \pm 0.60 & $0.78 \pm 0.13$ & $0.59 \pm 0.10$ \\
\hline VS176 & $3 \mathrm{~N}, 7 \mathrm{E}$ & $0-15$ & 9.2 & 11 & \pm 0.95 & $0.73 \pm 0.18$ & $0.73 \pm 0.17$ \\
\hline VS177 & $4 \mathrm{~N}, 7 \mathrm{E}$ & $0-15$ & 35 & 53 & \pm 2.1 & $0.81 \pm 0.18$ & $0.63 \pm 0.16$ \\
\hline VS178 & $4 \mathrm{~N}, 8 \mathrm{E}$ & $0-15$ & 19 & 17 & \pm 0.92 & $0.78 \pm 0.15$ & $0.55 \pm 0.10$ \\
\hline VS179 & $5 \mathrm{~N}, 8 \mathrm{E}$ & $0-15$ & 26 & 21 & \pm 1.5 & $0.84 \pm 0.25$ & $0.42 \pm 0.18$ \\
\hline VS180 & $\mathbb{N}, \sigma E$ & $0-15$ & $e$ & 1.0 & \pm 0.23 & $0.83 \pm 0.16$ & $0.28 \pm 0.10$ \\
\hline VS181 & $\mathbb{N}, 7 \mathrm{E}$ & $0-15$ & $e$ & 0.83 & \pm 0.29 & $0.47 \pm 0.16$ & $0.22 \pm 0.13$ \\
\hline VS182 & $6 \mathrm{~N}, 8 \mathrm{E}$ & $0-15$ & 3.8 & 3.0 & \pm 0.37 & $0.55 \pm 0.14$ & $0.29 \pm 0.12$ \\
\hline VS183 & $7 \mathrm{~N}, 6 \mathrm{E}$ & $0-15$ & 6.3 & 4.8 & \pm 0.50 & $0.97 \pm 0.19$ & $0.43 \pm 0.14$ \\
\hline VS184 & $\mathrm{ON}, \mathrm{OE}$ & $0-15$ & 18 & 13 & \pm 1.1 & $0.79 \pm 0.19$ & $1.1 \pm 0.18$ \\
\hline VS185 & $1 \mathrm{~S}, 10 \mathrm{E}$ & $0-15$ & 4.1 & 3.2 & \pm 0.43 & $0.82 \pm 0.14$ & $0.68 \pm 0.12$ \\
\hline VS186 & $3 S, 15$ & $0-15$ & 7.1 & 5.9 & \pm 0.52 & $0.84 \pm 0.16$ & $0.56 \pm 0.14$ \\
\hline VS187 & $3 S, 20 E$ & $0-15$ & 4.9 & 2.5 & \pm 0.46 & $0.92 \pm 0.17$ & $1.2 \pm 0.16$ \\
\hline VS188 & $19 \mathrm{~N}, 19 \mathrm{E}$ & $0-15$ & 7.1 & 5.7 & \pm 0.68 & $0.86 \pm 0.23$ & $0.41 \pm 0.17$ \\
\hline VS189 & $21 \mathrm{~N}, 19 \mathrm{E}$ & $0-15$ & 9.2 & 6.3 & \pm 0.71 & $0.62 \pm 0.16$ & $0.53 \pm 0.13$ \\
\hline VS190 & $20 \mathrm{~N}, 18 \mathrm{E}$ & $0-15$ & 5.6 & 3.8 & \pm 0.55 & $0.51 \pm 0.17$ & $0.17 \pm 0.04$ \\
\hline VS191 & $20 \mathrm{~N}, 20 \mathrm{E}$ & $0-15$ & 6.2 & 4.7 & \pm 0.64 & $0.67 \pm 0.15$ & $0.63 \pm 0.13$ \\
\hline VS192 & $27 \mathrm{~N}, 14 \mathrm{E}$ & $0-15$ & 7.3 & 3.8 & \pm 0.44 & $0.72 \pm 0.16$ & $0.59 \pm 0.16$ \\
\hline VS193 & $1.5 \mathrm{~S}, 0 \mathrm{E}$ & $0-15$ & 3.8 & 1.4 & \pm 0.38 & $0.97 \pm 0.17$ & $0.90 \pm 0.14$ \\
\hline
\end{tabular}


Table 3. (continued)

\begin{tabular}{|c|c|c|c|c|c|c|}
\hline \multirow{3}{*}{$\begin{array}{c}\text { Sample } \\
\text { I.D. }\end{array}$} & \multirow{3}{*}{$\underset{\text { location }}{\text { Grid }}$} & \multirow{3}{*}{$\begin{array}{l}\text { Depth } \\
\text { (cm) }\end{array}$} & \multicolumn{4}{|c|}{ Radionuclide concentration(pCi/g)a } \\
\hline & & & \multicolumn{2}{|c|}{$238 \mathrm{Uc}$} & \multirow[b]{2}{*}{$226 \mathrm{Ra}$} & \multirow[b]{2}{*}{ 232Th } \\
\hline & & & Field & $\overline{\mathrm{Lab}}$ & & \\
\hline VS194 & ON, 1E & $0-15$ & 13 & $9.9 \pm 0.93$ & $0.70 \pm 0.23$ & $0.30 \pm 0.16$ \\
\hline VS195 & $0 N, 1 W$ & $0-15$ & $e$ & $1.0 \pm 0.30$ & $0.93 \pm 0.16$ & $0.88 \pm 0.12$ \\
\hline VS196 & $1 N, 0 E$ & $0-15$ & 32 & $1.9 \pm 0.45$ & $0.81 \pm 0.18$ & $0.45 \pm 0.12$ \\
\hline VS197 & $1 \mathrm{~S}, 5 \mathrm{E}$ & $0-15$ & 0.38 & $1.5 \pm 0.39$ & $0.51 \pm 0.18$ & $0.20 \pm 0.14$ \\
\hline VS198 & $28 \mathrm{~N}, 19 \mathrm{E}$ & $0-15$ & 9.8 & $10 \pm 1.0$ & $0.83 \pm 0.23$ & $0.28 \pm 0.06$ \\
\hline VS199 & $27 \mathrm{~N}, 18 \mathrm{E}$ & $0-15$ & 11 & $7.5 \pm 0.80$ & $0.80 \pm 0.18$ & $0.56 \pm 0.13$ \\
\hline VS200 & $27 \mathrm{~N}, 20 \mathrm{E}$ & $0-15$ & 4.5 & $2.4 \pm 0.33$ & $0.70 \pm 0.15$ & $0.27 \pm 0.10$ \\
\hline VS201 & $26 \mathrm{~N}, 19 \mathrm{E}$ & $0-15$ & $e$ & $2.5 \pm 0.45$ & $0.46 \pm 0.16$ & $0.14 \pm 0.04$ \\
\hline VS202 & $2 \mathrm{~N}, 15 \mathrm{E}$ & $0-15$ & 2.4 & $2.4 \pm 0.54$ & $0.92 \pm 0.18$ & $0.86 \pm 0.17$ \\
\hline VS203 & $2 \mathrm{~N}, 16 \mathrm{E}$ & $0-15$ & 12 & $19 \pm 1.3$ & $0.99 \pm 0.25$ & $0.41 \pm 0.20$ \\
\hline VS212 & $9 \mathrm{~N}, 11 \mathrm{E}$ & $0-15$ & 18 & $11 \pm 1.0$ & $0.74 \pm 0.19$ & $0.74 \pm 0.16$ \\
\hline VS215 & $8 \mathrm{~N}, 11 \mathrm{E}$ & $0-15$ & 0.98 & $2.7 \pm 0.55$ & $0.61 \pm 0.21$ & $0.16 \pm 0.14$ \\
\hline VS229 & $2 \mathrm{~N}, 16 \mathrm{E}$ & $0-15$ & $e$ & $1.8 \pm 0.32$ & $0.58 \pm 0.14$ & $0.15 \pm 0.10$ \\
\hline VS230 & $5 \mathrm{~N}, 14 \mathrm{E}$ & $0-15$ & $e$ & $3.0 \pm 0.56$ & $0.49 \pm 0.19$ & $0.29 \pm 0.18$ \\
\hline VS231 & $9 \mathrm{~N}, 13 \mathrm{E}$ & $0-15$ & 18 & \pm 1.4 & $1.0 \pm 0.23$ & $0.73 \pm 0.16$ \\
\hline VS232 & $12 \mathrm{~N}, 15 \mathrm{E}$ & $0-15$ & $e$ & $5.2 \pm 0.61$ & $0.85 \pm 0.22$ & $0.17 \pm 0.13$ \\
\hline VS233 & $10 \mathrm{~N}, 12 \mathrm{E}$ & $0-15$ & 4.9 & $4.7 \pm 0.75$ & $0.63 \pm 0.18$ & $0.27 \pm 0.10$ \\
\hline VS234 & $13 N, 11 E$ & $0-15$ & 3.4 & $8.3 \pm 0.93$ & $0.83 \pm 0.21$ & $0.50 \pm 0.14$ \\
\hline VS235 & $16 \mathrm{~N}, 12 \mathrm{E}$ & $0-15$ & $e$ & $1.2 \pm 0.42$ & $0.62 \pm 0.22$ & $0.24 \pm 0.06$ \\
\hline VS236 & $9 \mathrm{~N}, 14 \mathrm{E}$ & $0-15$ & $e$ & $2.2 \pm 0.51$ & $0.72 \pm 0.19$ & $0.22 \pm 0.10$ \\
\hline VS237 & $13 \mathrm{~N}, 10 \mathrm{E}$ & $0-15$ & 15 & $13 \pm 1.2$ & $0.93 \pm 0.23$ & $0.76 \pm 0.17$ \\
\hline VS238 & $9 \mathrm{~N}, 12 \mathrm{E}$ & $0-15$ & $e$ & $2.5 \pm 0.49$ & $0.67 \pm 0.21$ & $0.29 \pm 0.17$ \\
\hline VS239 & $8 \mathrm{~N}, 13 \mathrm{E}$ & $0-15$ & 15 & $16 \pm 1.2$ & $0.82 \pm 0.20$ & $0.63 \pm 0.14$ \\
\hline VS240 & $12 \mathrm{~N}, 13 \mathrm{E}$ & $0-15$ & 2.2 & $4.5 \pm 0.52$ & $0.58 \pm 0.16$ & $0.13 \pm 0.03$ \\
\hline VS241 & $3.5 \mathrm{~S}, 18 \mathrm{~W}$ & $0-15$ & $e$ & $1.3 \pm 0.28$ & $0.81 \pm 0.13$ & $0.55 \pm 0.09$ \\
\hline VS242 & $5 S, 11 W$ & $0-15$ & 5.3 & $1.5 \pm 0.48$ & $0.81 \pm 0.20$ & $0.89 \pm 0.17$ \\
\hline VS243 & $4.5 \mathrm{~S}, 1.5 \mathrm{~W}$ & $0-15$ & 2.1 & $1.4 \pm 0.40$ & $0.81 \pm 0.23$ & $0.28 \pm 0.15$ \\
\hline
\end{tabular}

Biased samplesf

$\begin{array}{llllclll}\text { VB1 } & 33.5 \mathrm{~N}, 3.4 \mathrm{~W} & 0-15 & 85 & 73 & \pm 5.0 & 1.2 \pm 0.09 & 0.95 \pm 0.13 \\ \text { VB2 } & 38.5 \mathrm{~N}, 1 \mathrm{~W} & 0-15 & 66 & 39 & \pm 3.3 & 1.1 \pm 0.08 & 0.86 \pm 0.15 \\ \text { VB7 } & \text { S4, 41E } & 0-15 & 32 & 22 & \pm 1.4 & 1.1 \pm 0.07 & 0.84 \pm 0.11\end{array}$


Table 3. (continued)

\begin{tabular}{|c|c|c|c|c|c|c|}
\hline \multirow{3}{*}{$\begin{array}{c}\text { Sample } \\
\text { I.D. }\end{array}$} & \multirow{3}{*}{$\begin{array}{c}\text { Grid } \\
\text { location }^{b}\end{array}$} & \multirow{3}{*}{$\begin{array}{l}\text { Depth } \\
\text { (cm) }\end{array}$} & \multicolumn{4}{|c|}{ Radionuclide concentration( $\mathrm{pCi} / \mathrm{g})^{a}$} \\
\hline & & & \multicolumn{2}{|c|}{$238 \mathrm{U}^{c}$} & \multirow[b]{2}{*}{$226 \mathrm{Ra}$} & \multirow[b]{2}{*}{$232 \mathrm{Th}$} \\
\hline & & & $\overline{\text { Field }}$ & $\overline{\mathrm{Lab}}$ & & \\
\hline VB17 & $27 \mathrm{~N}, 19 \mathrm{E}$ & $0-15$ & 33 & \pm 1.7 & $0.84 \pm 0.07$ & $0.54 \pm 0.09$ \\
\hline VB18 & $19 \mathrm{~N}, 15 \mathrm{E}$ & $0-15$ & 15 & $11 \pm 1.5$ & $1.4 \pm 0.09$ & $1.0 \pm 0.14$ \\
\hline VB19 & $17 \mathrm{~N}, 14 \mathrm{E}$ & $0-15$ & 13 & $9.0 \pm 1.3$ & $1.3 \pm 0.08$ & $0.97 \pm 0.12$ \\
\hline
\end{tabular}

andicated counting error is at the $95 \%$ confidence level $( \pm 2 \sigma)$.

$b$ Locations are shown on Figs. 4 and 5.

c Field analyses provide a quick estimate of $238 \mathrm{U}$ concentrations for cleanup recommendations in the field and do not provide a counting error. Laboratory analyses provide the most accurate results. The samples for field analyses are from the same location as the samples analyzed at ORNL, but are not the same material. Discrepancies may be due to non-homogeneous contamination.

$d$ Systematic samples are collected without regard to gamma exposure rates.

eSample concentration was not distinguishable from background.

$f B i a s e d$ samples were collected from locations of previous anomalies. 
ORNL/TM-12968

\section{INTERNAL DISTRIBUTION}

\author{
1. K. J. Brown \\ 2-4. R. F. Carrier \\ 5. R. D. Foley \\ 6. R. C. Gosslee \\ 7. C. A. Johnson \\ 8-9. M. E. Murray \\ 10. P. T. Owen \\ 11-12. D. E. Rice \\ 13. D. A. Roberts \\ 14. R.E. Swaja
}

15. R. E. Rodriguez

16. M. S. Uziel

17. J. K. Williams

18. Central Research Library

19-21. Laboratory Records

22. Laboratory Records - RC

23. ORNL Patent Section

24. ORNL Technical Library, Y-12

25-30. MAD Records Center

\section{EXTERNAL DISTRIBUTION}

31. D. G. Adler, Former Sites Restoration Division, Oak Ridge Field Office, U.S. Department of Energy, P.O. Box 2001, Oak Ridge, TN, 37831-8723

32. W. L. Beck, ORISE, E/ESD, 1299 Bethel Valley Road, Oak Ridge, TN 37831

33. J. J. Fiore, Director, Office of Eastern Area Programs, Office of Environmental Restoration, Cloverleaf Bldg. (EM-24) U.S. Department of Energy, 19901 Germantown Rd., Germantown, MD 20874-1290

34. FUSRAP Document Center, Science Applications International Corporation, P.O. Box 2501, 301 Laboratory Road, Oak Ridge, TN, 37831

35. Albert Johnson, Program Manager, Formerly Utilized Sites Remedial Action Program, U.S. Department of Energy, Cloverleaf Bldg., 19901 Germantown Rd., Germantown, MD 208741290

36-41. K. R. Kleinhans, Y-12 Site Health Physics Supervisor, MK-Ferguson of Oak Ridge Co., P.O. Box 2011, Bldg. 9703-15, Oak Ridge, TN 37831-2100

42. L. K. Price, Director, Former Sites Restoration Division, Oak Ridge Field Office, U.S. Department of Energy, P.O. Box 2001, Oak Ridge, TN 37831-8723

43. Jack Russell, 12850 Middlebrook Road, Suite 210, Germantown, MD 20874

44. A. G. Toddings, FUSRAP Project Administrator Bechtel National, Inc., FUSRAP Department, Oak Ridge Corporate Center, 151 Lafayette Drive, P. O. Box 350, Oak Ridge, TN 37831-0350

45-47. W. Alexander Williams, Designation and Certification Manager, Division of Off-Site Programs, Office of Eastern Area Programs, Office of Environmental Restoration, Cloverleaf Bldg. (EM421), U.S. Department of Energy, 19901 Germantown Rd, Germantown, MD 20874-1290

48-49. Office of Assistant Manager, Energy Research and Development, DOE Oak Ridge Operations, P.O. Box 2001, Oak Ridge, TN 37831-8600

50-52. Office of Scientific and Technical Information, DOE, P.O. Box 62, Oak Ridge, TN 37831 


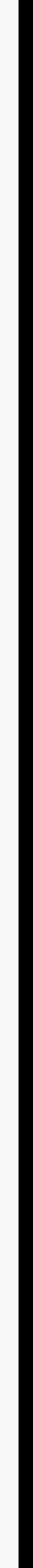

